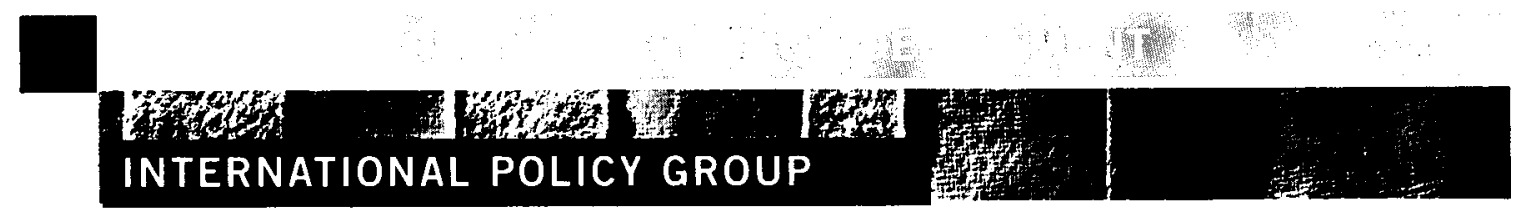

\title{
Recent
}

Developments in China's Labour Economy

Thomas G. Rawski

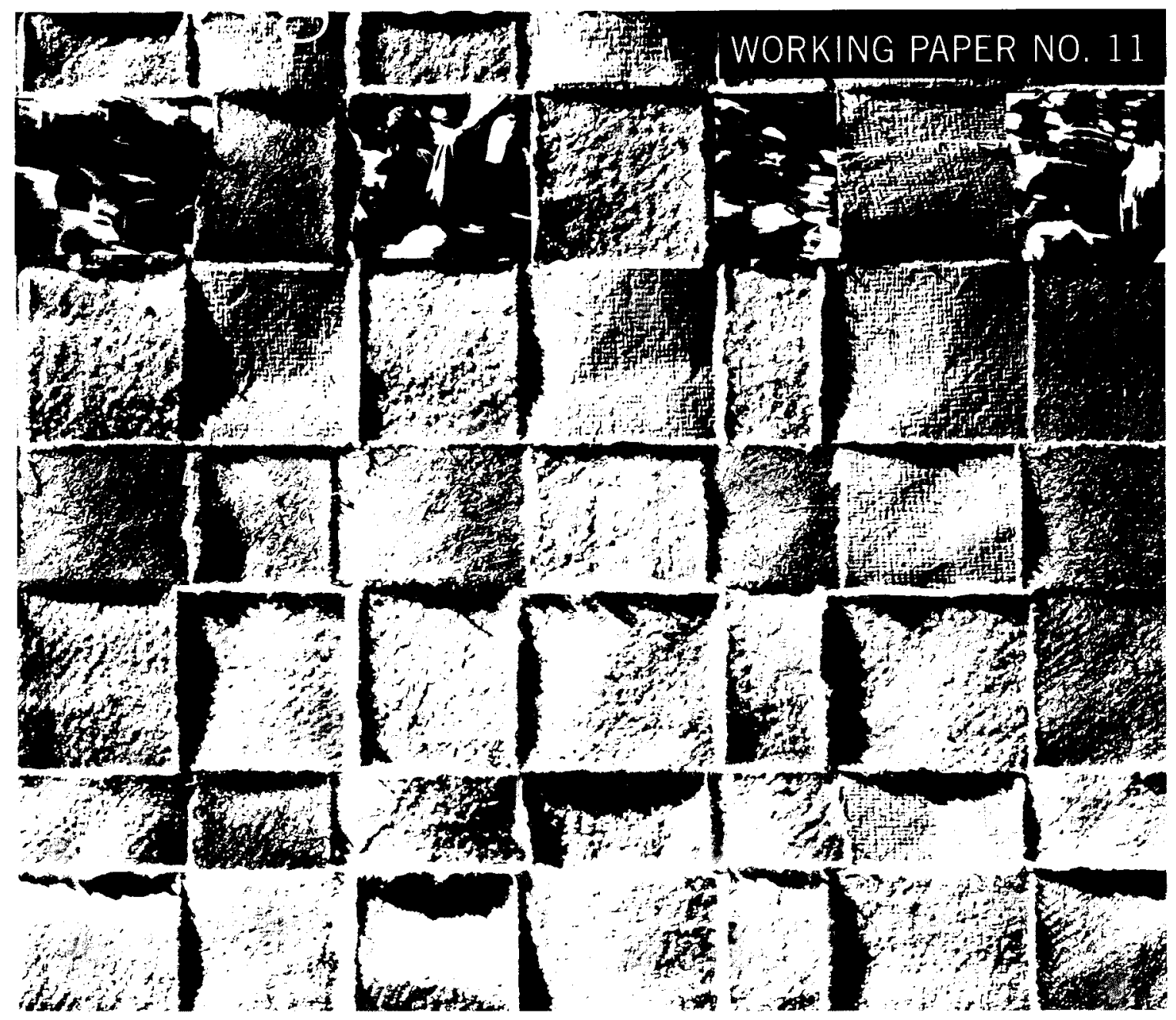





\title{
Recent Developments in China's Labour Economy
}

\author{
Working Paper No. 11
}

\author{
Thomas G. Rawski
}

\author{
International Policy Group \\ Policy Integration Department \\ International Labour Office \\ Geneva
}

October 2003 
Copyright $\mathbb{C}$ International Labour Organization 2003

Publications of the International Labour Office enjoy copyright under Protocol 2 of the Universal Copyright Convention. Nevertheless, short excerpts from them may be reproduced without authorization, on condition that the source is indicated. For rights of reproduction or translation, application should be made to the ILO Publications Bureau (Rights and Permissions), International Labour Office, CH-1211 Geneva 22, Switzerland. The International Labour Office welcomes such applications.

Libraries, institutions and other users registered in the United Kingdom with the Copyright Licensing Agency, 90 Tottenham Court Road, London W1T 4LP [Fax: (+44) (0)20 7631 5500; email: cla $(a$ cla.co.uk], in the United States with the Copyright Clearance Center, 222 Rosewood Drive, Danvers, MA 01923 [Fax: $(+1)$ (978) 750 4470; email: info@copyright.com] or in other countries with associated Reproduction Rights Organizations, may make photocopies in accordance with the licences issued to them for this purpose.

ISBN 92-2-115162-X

First published 2003

The designations employed in ILO publications. which are in conformity with United Nations practice, and the presentation of material therein do not imply the expression of any opinion whatsoever on the part of the International Labour Office concerning the legal status of any country, area or territory or of its authorities, or concerning the delimitation of its frontiers.

The responsibility for opinions expressed in signed articles, studies and other contributions rests solely with their authors, and publication does not constitute an endorsement by the International Labour Office of the opinions expressed in them.

Reference to names of firms and commercial products and processes does not imply their endorsement by the International Labour Office, and any failure to mention a particular firm, commercial product or process is not a sign of disapproval.

ILO publications can be obtained through major booksellers or ILO local offices in many countries, or direct from ILO Publications, International Labour Office, CH-1211 Geneva 22, Switzerland. Catalogues or lists of new publications are available free of charge from the above address. 


\section{Recent Developments in China's Labour Economy}

\section{Contents}

Preface

ii

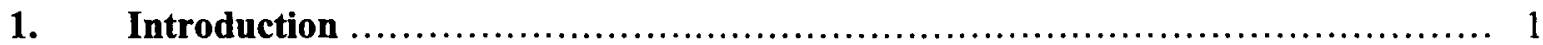

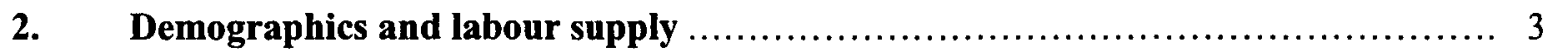

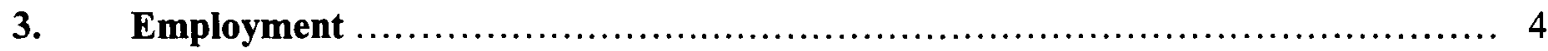

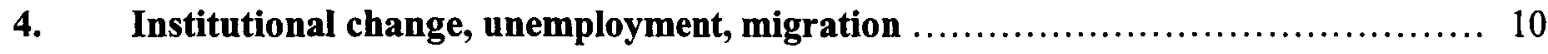

4.1 Collapse of the urban tenure system ....................................... 10

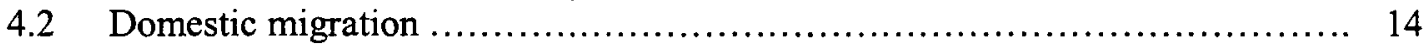

4.3 Growing penetration of market forces ...................................... 15

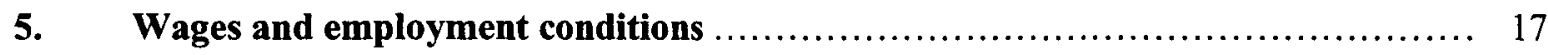

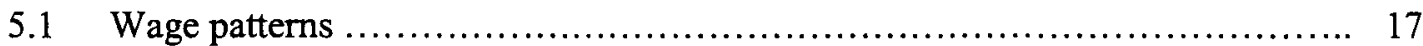

5.2 Employment conditions ............................................... 23

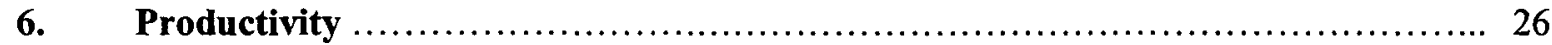

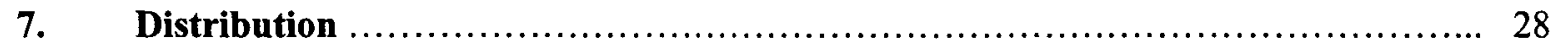

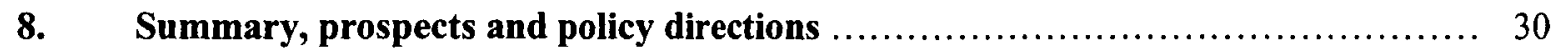

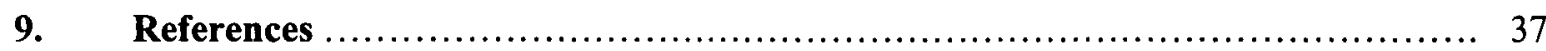




\section{PREFACE}

Within the Policy Integration Department, the International Policy Group focuses on developments in the global economy and undertakes analytical work with a view to promoting the ILO's Decent Work Agenda in the formulation of international economic policy. IPG serves as the technical secretariat to the ILO Governing Body Working Party on the Social Dimension of Globalization.

This working paper is an output of the first phase of a research project funded by the Department for International Development (DFID) of the United Kingdom Government, on the impact of opening to trade and Foreign Direct Investment on employment, income distribution and poverty in developing countries. In this phase of the project the studies are based on international cross-section data. The second phase, currently underway, will consist of country studies

In his contribution, Thomas G. Rawski analyses the Chinese labour market, presenting new evidences about wages and employment conditions, and describes recent trends in China's within-country income distribution with particular reference to geographical and urban/rural income disparities. On the basis of these analyses and data, interesting policy implications are derived.

The views expressed are those of the author.*

As an INTEGRATION Working Paper, this document is intended to stimulate further debate on key issues of globalization and its social dimension.

September 2003

Eddy Lee

Director

International Policy Group

Policy Integration Department

The author, who assumes sole responsibility for what follows, has benefited from Yifan Zhang's expert research assistance and from the generosity of numerous colleagues, including Loren Brandt, Kam Wing Chan, Sarah Cook, Denise Hare, Angang Hu, Gary Jefferson, Albert Keidel, James Kaising Kung, Nicholas Lardy, Margaret Maurer-Fazio, Joydeep Mukherji, Albert Park, Scott Rozelle, Terry Sicular, Dorothy Solinger, Loraine West, Calla Wiemer, Tim Wright, Dennis Yang, Haihui Zhang, Linxiu Zhang, and Yaohui Zhao. 


\section{Introduction}

The years since 1990 have brought major changes in many dimensions of China's large and dynamic economy. At the macroeconomic level, the decade began with a rapid recovery of momentum from a short downturn caused by a combination of efforts to control inflation and fallout from the suppression of urban protests in June 1989. High-speed growth rekindled inflationary pressures. Once again, the government applied strong measures to cool the economy. Apparent success in reducing inflation without eroding the momentum of growth proved shortlived, as a combination of structural imbalances and the impact of the 1997/98 Asian crisis sharply reduced the pace of growth.

Although macroeconomic performance was highly uneven, the economy recorded substantial growth of aggregate and per capita output and income during the 1990s. Structural change was notable in many areas, including a continuing decline in the importance of agriculture, the emergence of new growth poles in electronics, telecommunications, and finance, continued increase in the scale and sophistication of foreign investment and export-oriented manufacturing, and rapid expansion of income inequality.

A combination of government policy and decentralized initiatives generated major shifts in the institutional structure of China's economy. Although the late 1990s brought important changes that expanded the central government's capacity to control the economy, the scope and power of market forces undoubtedly achieved broad gains during the $1990 \mathrm{~s} .^{1}$

Issues of employment and unemployment, labour compensation, wage differentials, working conditions, migration, job mobility, and employment security figured prominently in all of these developments. At times, changes in the labour arena appeared to drive developments elsewhere. On other occasions, shifts on the labour scene came in response to changes in other segments of the economy.

This report reviews Chinese labour market developments since 1990. Its objective is to review major shifts, to highlight important interactions between labour and other aspects of China's dynamic economy, and to indicate the likely path of trends in the determination of employment and wages.

To do this, we focus successively on demographics, employment, unemployment, migration, productivity, wages, and distribution, and conclude with speculation about possible policy responses to China's growing problem of excess labour supply.

Readers should be aware of difficulties surrounding the data underlying the following analysis of Chinese labour issues. In addition to the general cautions applicable to any large, lowincome nation with a large farm sector, several specific issues merit attention: ${ }^{2}$

\footnotetext{
' These items are pursued in Rawski 2000a; Rawski 2001b.

${ }^{2}$ For details, see Rawski and Xiao (2001) and the accompanying symposium on Chinese economic statistics.
} 
- Coincidence of rapid institutional change with frequent shifts in the scope and coverage of statistics related to employment, labour, and wages creates inconsistencies and discontinuities within standard statistical measures.

- $\quad$ Reduced incentive to cooperate with official statistical agencies, diversion of resources from the collection and processing of statistics, and widespread manipulation of data at the microeconomic level and within local and provincial governments appear to have expanded error margins and reduced the reliability of many types of economic data during the $1990 \mathrm{~s}$.

- Beginning in 1998, strong political pressures gave rise to what Chinese commentators call a "wind of falsification and embellishment" (jiabao fukuafeng), which has led to systematic overstatement of macroeconomic aggregates at the provincial, and, in all probability, at the national level. ${ }^{3}$

Table 1 illustrates difficulties with recent data on urban employment, the most reliable component of China's statistics on labour, wages, and unemployment. In 1990, total urban employment tallied precisely with the sum of components. Data for 1996-2000 show an increasing gap between the two figures, which in the final year amounts to over 60 million persons. The statistics yearbook explains that the total is adjusted on the basis of "data obtained from the sample surveys on population changes" (Yearbook, p. 107). This indicates a commendable use of surveys to improve the quality of employment data. It also illustrates the wide range of uncertainty surrounding basic information underpinning any quantitative analysis of recent trends in China's economy.

Although this report will point to the most serious distortions associated with specific types of data, there is no practical alternative to relying on standard figures issued by China's National Bureau of Statistics (NBS, formerly known as the State Statistics Bureau). Although NBS produces "internal" compilations with restricted circulation, these sources generally elaborate data that appear in open sources.

${ }^{3}$ Official measures of real GDP indicate annual real growth of 7.8, 7.2, 8.0, and 7.3 per cent beginning in 1997/98. Referring to 1998 , Chinese observers speak of "universal falsification of statistics, as a 'statistical bubble' works its way up through the system, and provides mistaken reportage to the decision-making levels" (Meng 1999, p.78). Premier Zhu Rongji complained in Mar. 2000 that "falsification and exaggeration are rampant" (Nation 2000). Available evidence suggests near-zero growth in 1998 and 1999. This author shares the views of "many economists [who] say the country's real economic growth rate is, at most, half of that reported" (Smith 2001). (For details, see Rawski 2001a; Rawski 2001c; Rawski 2001d). 
Table 1: Urban employment reconciliation

\begin{tabular}{|c|c|c|c|c|c|}
\hline & 1996 & 1997 & 1998 & 1999 & 2000 \\
\hline \multicolumn{6}{|l|}{ Urban formal employment (million) } \\
\hline State sector & 112.44 & 110.44 & 90.58 & 85.72 & 81.02 \\
\hline Urban collective & 30.16 & 28.83 & 19.63 & 17.12 & 14.99 \\
\hline Cooperatives & n.a. & n.a. & 1.36 & 1.44 & 1.55 \\
\hline Joint ownership & 0.49 & 0.43 & 0.48 & 0.46 & 0.42 \\
\hline Limited liability corp. & n.a. & n.a. & 4.84 & 6.03 & 6.87 \\
\hline Shareholding & 3.63 & 4.68 & 4.10 & 4.20 & 4.57 \\
\hline Private firms & 6.20 & 7.50 & 9.73 & 10.53 & 12.68 \\
\hline Funded from SAR Hong Kong, Macao, Taiwan (China) & 2.65 & 2.81 & 2.94 & 3.06 & 3.10 \\
\hline Foreign funding & 2.75 & 3.00 & 2.93 & 3.06 & 3.32 \\
\hline Self-employed individuals & 17.09 & 19.19 & 22.59 & 24.14 & 21.36 \\
\hline Sum of components (A) & 175.41 & 176.88 & 159.18 & 155.76 & 149.88 \\
\hline Urban employed persons (B) & 212.74 & 212.74 & 212.74 & 212.74 & 212.74 \\
\hline \multicolumn{6}{|l|}{ Unexplained residual (=B-A) } \\
\hline Million workers & 37.33 & 35.86 & 53.56 & 56.98 & 62.86 \\
\hline Per cent of urban employed & 17.50 & 16.90 & 25.20 & 26.80 & 29.50 \\
\hline \multicolumn{6}{|l|}{ Source: Yearbook 2001, p. 107.} \\
\hline \multicolumn{6}{|l|}{$\begin{array}{l}\text { Note: The residual arises because total urban employment } \\
\text { is adjusted using "data obtained from the sample surveys }\end{array}$} \\
\hline
\end{tabular}

\section{Demographics and labour supply}

Table 2 summarizes major data series relating to population and labour force. Two measures: "economically active population" (jingji huodong renkou) and "employment" (congye renkou) are offered as approximate measures of labour force. 4 Although these figures are far from precise, they do show a declining trend in the growth of the population and labour force in absolute numbers as well as percentage gains. This reflects the long-term impact of energetic population control measures and rising incomes on reproductive behaviour. Focusing on the more complete measure of labour force (Series B) annual increments decline from 13.4 million in $1979 / 80$ to 8.9 million in $1990 / 91$ and 5.6 million in 1999/2000.

4 The relation between these measures is not clear. Urban data for 1998, for example, show that the "economically active population" exceeds "employment" by 13.1 million persons, which is far larger than registered urban unemployment of 5.7 million. (See Labour 1999, pp. 63, 83). 
Table 2: Population and labour force

\begin{tabular}{|c|c|c|c|c|c|c|c|c|}
\hline \multirow{2}{*}{$\begin{array}{r}\text { Year-end } \\
\text { Population } \\
\text { Million }\end{array}$} & \multirow{2}{*}{$\begin{array}{r}\text { Annual } \\
\text { increment } \\
\text { million }\end{array}$} & \multirow{2}{*}{$\begin{array}{r}\text { RNI } \\
\text { per cent }\end{array}$} & \multicolumn{2}{|c|}{ Aggregated data } & \multirow{2}{*}{$\begin{array}{r}\text { Annual } \\
\text { increment } \\
\text { million } \\
\text { [Series A] }\end{array}$} & \multirow{2}{*}{ 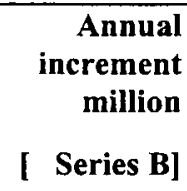 } & \multicolumn{2}{|c|}{$\begin{array}{r}\text { Per cent annual } \\
\text { increase }\end{array}$} \\
\hline & & & [Series A] & [Series B] & & & [Series A] & Series B] \\
\hline & & 1.50 & & 423.6 & & 13.4 & & 3.3 \\
\hline & & & & 498.7 & & 16.7 & & 3.9 \\
\hline & & 1.58 & & 639.1 & & $* 85.8$ & & 15.5 \\
\hline Population figures & & & & & Labour for & & & \\
\hline & 14.9 & 1.40 & & 648.0 & & 8.9 & & 1.4 \\
\hline & 13.5 & 1.22 & & 655.5 & & 7.5 & & 1.2 \\
\hline & 13.5 & 1.22 & 609.6 & 663.7 & & 8.2 & & 1.3 \\
\hline & 13.3 & 1.20 & $* 687.7$ & 672.0 & $* 78.1$ & 8.3 & 12.8 & 1.3 \\
\hline & 12.7 & 1.11 & 696.6 & 679.5 & 8.9 & 7.5 & 1.3 & 1.1 \\
\hline & 12.7 & 1.11 & *696.6 & 688.5 & $* 0.0$ & 9.0 & 0.0 & 1.3 \\
\hline & 12.4 & 1.05 & 705.8 & 696.0 & 9.2 & 7.5 & 1.3 & 1.1 \\
\hline & 11.8 & 1.00 & 714.1 & 699.6 & 8.3 & 3.6 & 1.2 & 0.5 \\
\hline & 11.0 & 0.92 & 719.8 & 705.9 & 5.7 & 6.3 & 0.8 & 0.9 \\
\hline & 6.7 & 0.53 & & 711.5 & & 5.6 & & 0.8 \\
\hline
\end{tabular}

\section{Employment}

Table 3 summarizes the composition and sectoral attachment of China's vast work force. With expansion of the labour force growth running ahead of population growth, China's labour force participation rate increased marginally from the high level recorded in prior years. Urban formal employment increased during the 1990s, but at a sharply reduced rate. This slowdown in urban job growth parallels the emergence of substantial open unemployment in China's cities. Within the urban work force, the share of female workers has remained roughly constant. 
Table 3: Basic data on population and employment, 1980-2000 (million persons and percentage)

\begin{tabular}{lrrrrr}
\hline Category & $\mathbf{1 9 8 0}$ & $\mathbf{1 9 9 0}$ & $\mathbf{2 0 0 0}$ & $\begin{array}{r}\text { Average growth } \\
\mathbf{1 9 8 0 - 9 0}\end{array}$ & $\mathbf{1 9 9 0 - 0 0}$ \\
\hline $\begin{array}{l}\text { 1. Population } \\
\text { 2. Increase (per cent) }\end{array}$ & 987.0 & 1143.3 & 1265.8 & 1.5 & 1.0 \\
& 1.19 & 1.44 & 0.53 & & \\
3. Labour force & 423.6 & 639.1 & 711.5 & $* 3.0$ & 1.1 \\
4. Urban formal employees & 104.4 & 140.6 & 146.6 & 3.0 & 0.4 \\
5. Labour force composition & & & & & \\
5A. Primary & 291.2 & 384.3 & 355.8 & 2.8 & -0.8 \\
5B. Secondary & & 136.5 & 160.1 & 5.9 & 1.6 \\
5C. Tertiary & 77.1 & 118.3 & 195.7 & 7.9 & 5.2
\end{tabular}

Shares (per cent)

Participation rate

56.2

Female workers\#

Primary

60.1

50.0

Secondary

Tertiary

*based on growth during the 1980/89 period. The series rises by an improbable figure of 87 million workers during that period, presumably reflecting adjustments based on the 1990 population census (see Labour 2000, p. 9).

\# proportion of female workers in units under state, urban collective, or "other" ownership. These figures exclude domestic private enterprises and self-employed individuals.

Sources: Except as noted, data for 1980 and 1990 from Rawski 1999. Data for 2000 are from Yearbook 2001, pp. 91, 107, from Table 1 (RNI for 2000; urban formal employment). Data on female employment are from Labour 2000, p. 15 and Labour 1995, p. 26.

Table 3 also displays important trends in the sectoral attachment of China's work force. The 1990 s brought a continued decline in the share of workers engaged in farming and other primary production work. In contrast with earlier data, the absolute number of primary workers now 
shows a distinct downward movement. ${ }^{5}$ Large inflows of foreign investment, most directed towards manufacturing, have not prevented a sharp decline in employment growth among China's secondary industries, a category dominated by manufacturing.

As a result, the proportion of workers in secondary trades showed only a slight rise during the 1990s. Service-sector employment, by contrast, showed continued rapid growth both in terms of numbers of workers and share of total employment. This reflects both the normal process of economic development and the continuing (but as yet incomplete) process of relaxing longstanding barriers that limit entry of new firms into a number of important service trades. ${ }^{6}$

Table 4 summarizes changes in formal employment. Following Chinese statistical practice, the totals include figures for domestic private business. ${ }^{7}$ The national data show considerable growth of formal employment during the 1990s. They also reveal a distinct slowdown in the pace of job creation: the national total rose by 6.2 per cent between 1980 and 1990 , but by only 2.1 per cent during the subsequent decade. These figures may understate the magnitude of the drop-off in job creation because the underlying data appear to overstate employment in one major category, township and village enterprises (TVEs) at the end of the 1990s. China's 1995 industrial census revealed massive exaggeration in the TVE statistics compiled by the Ministry of Agriculture. ${ }^{8}$ The sharp fluctuations in TVE employment reported for 1996/98 may reflect an effort to improve the TVE data, followed by a return to the prior pattern of chronic overstatement. Since it is unlikely that actual TVE employment increased after 1996/97, TVE employment in 2000 may be closer to 90 million than to the figure of 127 million reported for 1999 . Insertion of the lower figure into Table 4 would push nationwide growth of formal employment during 1990/2000 below one per cent per year.

Whatever the actual level of TVE employment at the end of the 1990s, the figures compiled in Table 4 indicate fundamental changes in China's employment dynamics. Expansion of formal employment during the $1990 \mathrm{~s}$ is entirely attributable to increases in rural jobs. The urban employment figure for 2000 is virtually identical with the total for 1990 . Furthermore, the locus of job expansion has shifted from state-owned enterprises (SOEs), urban collectives, and TVE firms, which absorbed the largest numbers of workers during the 1980 s, to firms under "other" ownership, a mixed group that includes domestic shareholding firms and enterprises with partial or full foreign ownership, and to domestic private business. Employment at SOEs and urban collectives dropped sharply. As a result, growth of formal employment during the 1990s is primarily (or, if TVE employment remained roughly constant during the 1990s, entirely) attributable to the expansion of job opportunities provided by domestic private and shareholding firms and by foreign-invested enterprises. This shift has important policy implications, which are discussed in the concluding section.

\footnotetext{
5 Official data appear to overstate China's farm work force. Rawski and Mead (1998) conclude that the number of "phantom farmers" actually working outside agriculture may be as high as 100 million. They argue that the decline in the absolute number of farm workers began in the 1980s.

6 See Guo 1999. At present, the main purpose of entry barriers is to protect the pricing power and profits of incumbent state enterprises. Relaxation of barriers would expand competition, reduce prices, increase volume, and therefore raise employment in telecommunications and other currently protected sectors.

7 These figures, which are no doubt less reliable than the figures for other employment categories, are the sum of two components: private companies employing eight or more workers and self-employed or individual workers (including businesses with fewer than eight employees).

${ }^{8}$ Vice Premier Zou Jiahua announced the results of the 1995 industrial census showing that "After striking out phoney [sic] statistics, the listed number of township enterprises in China has decreased by one third. . . and their output figure dropped by nearly 40 per cent" (Wu 1997).
} 


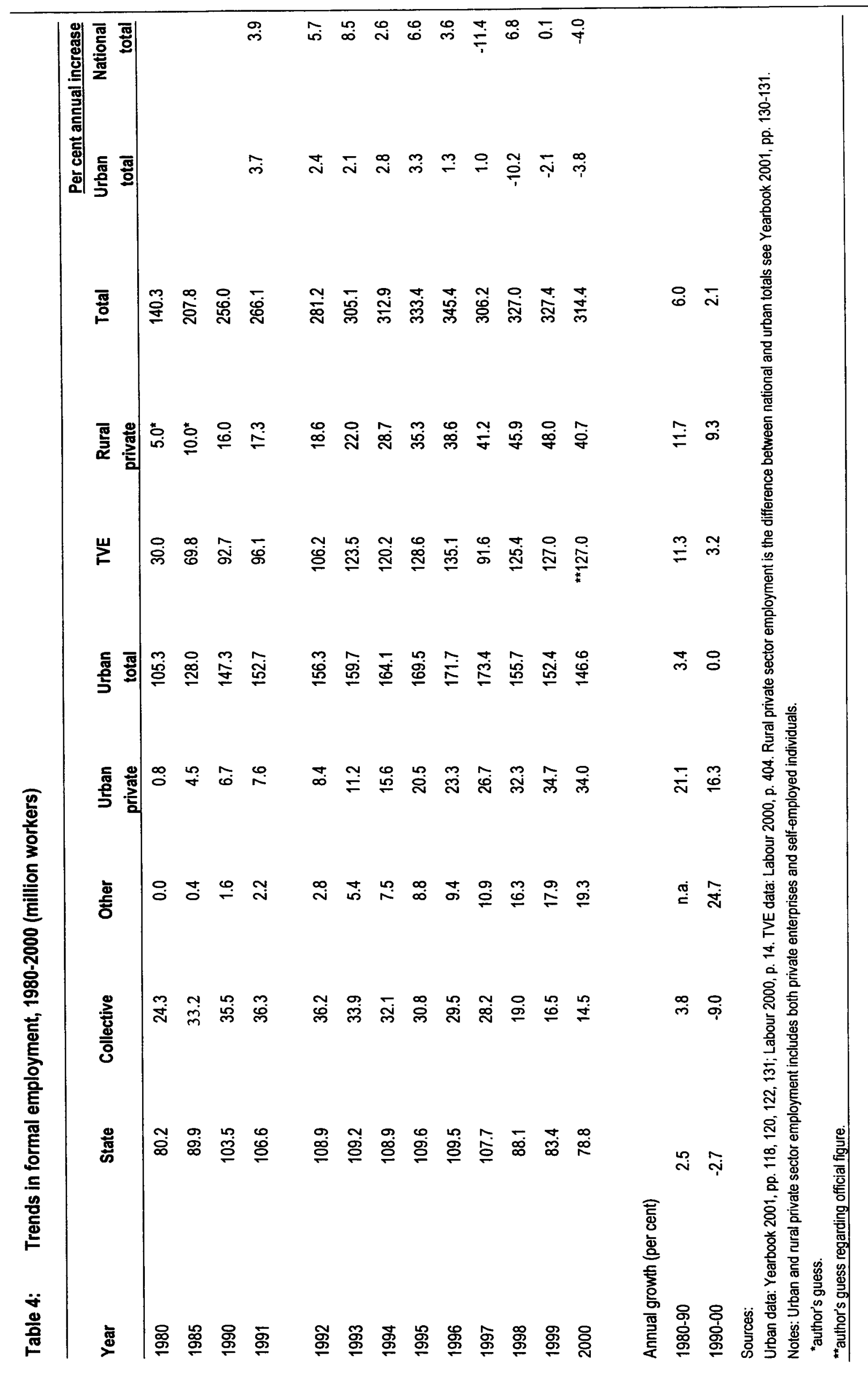


Reduced absorption of labour into regular employment implies that growing numbers of workers are pushed into (or obliged to remain within) the unorganized sector, which includes informal work, self-employed farming, and various degrees of un- and underemployment. Table 5 quantifies this recent development. During the 1980s, rapid growth created an average of over 10 million formal jobs per year. The pace of job creation accelerated during the early 1990s. With a slowdown in labour force growth, employment prospects facing Chinese workers improved remarkably, with millions transferring every year from farming and other informal occupations into regular employment.

Table 5: Patterns of labour absorption, $1980-2000$ (million workers)

\begin{tabular}{|c|c|c|c|}
\hline & $1980-90$ & 1990-95 & $1995-2000$ \\
\hline Labour force increment & 215.5 & 40.4 & 32.0 \\
\hline \multicolumn{4}{|l|}{ Formal sector labour absorption } \\
\hline \multicolumn{4}{|l|}{ Urban } \\
\hline State-owned enterprises & 23.3 & 6.1 & -30.7 \\
\hline Urban collectives & 11.2 & -4.7 & -16.3 \\
\hline Other ownership & 1.6 & 7.2 & 10.5 \\
\hline Urban private & 5.9 & 13.8 & 13.5 \\
\hline \multicolumn{4}{|l|}{ Rural } \\
\hline Township-village enterprises & 62.7 & 35.9 & -1.6 \\
\hline Rural private & 11.0 & 19.3 & 5.4 \\
\hline Formal sector total & 115.7 & 77.6 & -19.2 \\
\hline \multicolumn{4}{|l|}{ Of which: } \\
\hline Urban & 42.0 & 22.4 & -23.0 \\
\hline Rural & 73.7 & 55.2 & 3.8 \\
\hline Informal sector* & 99.8 & -37.2 & 51.2 \\
\hline \multicolumn{4}{|l|}{ Annual averages } \\
\hline Labour force increment & 21.6 & 8.1 & 6.4 \\
\hline Formal sector labour absorption & 11.6 & 15.5 & -3.8 \\
\hline Informal sector labour absorption & 10.0 & .7 .4 & 10.2 \\
\hline \multicolumn{4}{|c|}{$*_{\text {Residual, including unemployment and under-employment. }}$} \\
\hline Source: Rawski 1999; Tables 2 and 4 above & & & \\
\hline
\end{tabular}


Table 5 shows that employment prospects deteriorated dramatically after 1995 , with large numbers pushed out of the formal sector. ${ }^{9}$ Slow growth of labour demand in the formal sector arises from several factors:

- the collapse of tenure provisions that had formerly protected the majority of urban workers from market pressures

- possible large-scale substitution of informal for formal workers

- an apparent steep decline in economic growth that is not reflected in official statistics.

The first and second of these factors point to institutional change as a major source of recent labour market developments.

Agriculture remains the largest source of informal employment. Reforms begun during the late 1970s allocated land use rights to each village household. Local governments periodically redistribute farmland on the basis of demographic and other changes. Agricultural land is typically cultivated by the household to which it is assigned. However, recent studies find a growing frequency of rental transactions among villagers, particularly in regions with diverse and well-developed rural economies. ${ }^{10}$

For China, as for other low-income nations, there are no precise estimates of the number of workers engaged in farming. Standard figures, which, as noted above, grow slowly during the 1980 s and begin to show a decline during the 1990s, appear to be residuals derived by subtracting employment in township-village enterprises, local government, and other activities from estimates of the economically active population. Alternate figures derived using output of specific agricultural products and estimates of unit labour requirements consistently produce much smaller estimates of farm labour requirements. ${ }^{11}$

Despite the paucity of reliable figures, it appears likely that the labour resources devoted to farming continued to decline during the 1990s. Overall, farmers faced increasingly unfavourable demand conditions during the 1990s, especially in regions with limited choice of cropping patterns. This was particularly evident after 1996, when profit margins eroded, and sometimes disappeared under pressure from steep declines in farm-gate prices and escalating official demands in the form of taxes and fees. ${ }^{12}$ Information about sugar provides a small but informative illustration: between 1996 and 2000, excess capacity pushed the price of manufactured sugar from Y4,138 to Y2,762 per ton. Not surprisingly, farm gate prices also declined, from Y260 to Y147 per ton of sugar cane, pushing the grower's profit margin from Y107 to Y12 per ton of cane (An 2001, p. 38). Such changes led

\footnotetext{
${ }^{9}$ Table 5 is based on the standard figures for TVE employment. Since, as noted above, these may be overstated, it is possible that the results exaggerate formal employment growth and understate the expansion of the informal work force during 1995/2000.

${ }^{10}$ A number of studies find that approximately 5-6 per cent of cultivated land is rented out. The figure reaches 8-10 per cent in developed regions and 1-2 per cent in the hinterland (Chen 2001, p. 15; see also Kung 2001).

${ }^{11}$ See Poverty 2001; Rawski and Mead 1998. These calculations (and similar analysis by Chinese economists) explicitly or implicitly depend on data for cultivated acreage. These figures are widely believed to underestimate actual circumstances. The standard crop output figures incorporate adjustments for underreporting of acreage. The accuracy of these adjustments directly affects the reliability of estimated labour requirements.

${ }^{12}$ Rampant fee collection (luan shoufei) is a major theme of writings on the political economy of rural China. China's government has struggled to enforce a 5 per cent limit on the proportion of rural household income that local governments can take in taxes and fees. The latest policy effort to reduce farmers' burdens replaces multiple fees with a simpler and more transparent tax levy (Zhao 2001).
} 
to widespread complaints that farmers "raise production but cannot raise their incomes," and to reports that large segments of the farm population have suffered declining incomes during the late 1990 s. $^{13}$

These conditions push villagers in the direction of leaving the land. Important institutional changes, discussed below, have sparked continued expansion of out-migration from China's villages despite a major slowdown in urban growth.

\section{Institutional change, unemployment, migration}

China is the prime example of gradualism in the transition from socialism. Transformation of labour markets and employment conditions, especially in cities and in the state sector, was notably absent from early reform initiatives. As late as 1990 , the rigid systems associated with state-sector employment - employee tenure, narrow wage differentials, and extensive employer-provided benefits (housing, pensions, health care, education) - continued to dominate the urban labour scene, so much so that reviews of China's first reform decade commented on retardation in labour market development and decried the "failure" of labour reform (Korzec 1992).

Despite limited accomplishments, a coalition favouring meaningful reform gradually emerged. Economists pointed to the vast future cost of unfunded mandates for pensions and other benefits. An "optimal labour" programme invited managers to design (but not implement) measures to trim redundant workers (Jefferson and Rawski 1992). Regulations on the management of state enterprises, promulgated in 1992, assigned decision-making authority over employment and wage matters to enterprise managers.

These measures, together with broader economic developments, accelerated the transformation of institutional structures surrounding China's labour markets. By the end of the 1990s, employment arrangements involved less segmentation, fewer rigidities, and far greater market influence than at the beginning of the decade. Two major changes - the collapse of urban tenure arrangements and large-scale migration of villagers into the cities and a plethora of important, but less dramatic reforms, contributed to dramatic changes in labour market arrangements.

\subsection{Collapse of the urban tenure system}

Despite some evidence of growing links between urban wages and enterprise financial outcomes (Rawski 1994), officially mandated reforms of urban employment and wages remained largely ineffectual until the intensification of competition sparked by increasing entry of TVEs, domestic private firms, and foreign-invested enterprises into a growing array of sectors. This new competition in product markets formerly dominated by urban-based state-owned enterprises created growing financial pressure on costs and profits. The dynamic is simple: firms burdened with expensive, poorly motivated workers and an array of costly fringe benefits cannot survive direct competition with rivals whose operations escape these constraints.

13 Zhao (2001) reports reductions in farmers" "absolute incomes" in the "central and western regions and major grain-producing areas" (p. 53). Wang Mengkui finds that "since 1997, 48 per cent of peasant households have experienced a drop in net income" (see Schob 2001), which refers Wang's article "Dangqian shehui jingji fazhanzhong xuyao yanjiu de wenti" (Problems Requiring Study in Current Socioeconomic Development) reprinted in Guomin jingji guanli, 6, No. F10 (2001). See also Lu et al. 2001; Wang 2001b). 
Although national and local authorities adopted (and continue to pursue) defensive measures intended to protect incumbent urban workers and their employers, traditional tenure arrangements began to crack about 1993, when state enterprise managers in Shanghai were allowed to lay off redundant workers as long as open unemployment remained within specific limits. The tenure system collapsed soon thereafter, as massive segments of the urban work force were shunted into a new arrangement called xiagang or furlough. Although the exact terms of furlough are subject to considerable variation, the key elements are consistent: furloughed employees receive no work assignments and need not report to work. They are entitled to (but do not always receive) small stipends and fringe benefits from their employers. Furloughed workers maintain residual ties to their ex-employers.

Table 6 summarizes available information about the scale of furloughs, which have disproportionately affected women, workers with limited education, and employees in late middle age. ${ }^{14}$ Since the term xiagang has no exact definition, these figures cannot be precise. What is beyond doubt, however, is that xiagang has effectively shattered China's socialist tradition of lifetime tenure for regular urban workers, that the number of furloughed urban workers is large - quite possibly in excess of 30 million, that furloughed workers face sharply reduced economic circumstances, and that they often encounter difficulty in reentering the urban labour market.

Table 6: Estimates of numbers of workers furloughed, 1993-2001 (millions)

\begin{tabular}{lrr}
\hline Year & New layoffs & Cumulative total of layoffs \\
\hline 1993 & $3.00^{*}$ & $3.00^{*}$ \\
1994 & $0.60^{*}$ & $3.60^{*}$ \\
1995 & $2.04^{*}$ & $5.64^{*}$ \\
1996 & $2.26^{*}$ & $8.91^{*}$ \\
1997 & $4.0^{* *}-5.1 \#$ & $11.51^{*} ; 14 \#$ \\
1998 & $7.4+$ & 16.0 \\
1999 & $7.8+$ & \\
2000 & $6.5 * 4$ \\
* Taken or calculated from Ma 1999, p. 84. & \\
"* Measures 1999, p. 4. & \\
\# Yang Yixiong 1998, p. 221. & \\
+ Internet documents provided by Zhang Wenkui. \\
+ Labour 1999, p. 441; 76 per cent of newly laid-off workers came from the state sector. \\
+ Labour 2000, p. 409; 79 per cent of newly laid-off workers came from the state sector. \\
* Zhang Liqun 2001, p. 26 (state sector only). \\
\hline
\end{tabular}

${ }^{14}$ Surprisingly, the share of female employees in the formal work force (Table 3) has increased despite the well-documented tendency of women workers to suffer a disproportionate share of layoffs (Appleton et al. 2001). 
With the spread of xiagang, China's cities now confront large-scale open unemployment on a scale unknown since the earliest days of the People's Republic. Official measures, summarized in Table 7 , are universally viewed as understating actual unemployment by a wide margin. There are three major difficulties. The official measure of the unemployed is limited to registered urban residents. Furthermore, workers on furlough retain a nominal affiliation with their former employers, and are therefore excluded from the jobless count even though, as Solinger and others have demonstrated, many of them are reduced to circumstances of dire poverty (Solinger forthcoming). Finally, the official total excludes large numbers of workers idled by the closure of loss-making or bankrupt enterprises. ${ }^{15}$

Table 7: Official and alternate rates of urban unemployment (unemployment as percentage of registered urban population)

\begin{tabular}{cccc}
\hline Year & $\begin{array}{l}\text { Number of registered } \\
\text { unemployed (millions) }\end{array}$ & $\begin{array}{l}\text { Official } \\
\text { unemployment rate }\end{array}$ & $\begin{array}{l}\text { Alternate } \\
\text { unemployment rate }\end{array}$ \\
\hline 1985 & 2.4 & 1.8 & n.a. \\
1990 & 3.8 & 2.5 & n.a. \\
1993 & 4.2 & 2.3 & $3.3-3.7$ \\
1994 & 4.8 & 2.6 & $3.6-4.1$ \\
1995 & 5.2 & 2.9 & $4.0-4.7$ \\
1996 & 5.5 & 3.0 & $4.9-5.9$ \\
1997 & 5.7 & 3.1 & $5.6-6.9$ \\
1998 & 5.9 & 3.1 & $7-8$ \\
1999 & 6.2 & 3.1 & 8.9 \\
2000 & & 3.1 & 8.3
\end{tabular}

Sources: Registered unemployed from Labour 1987, p. 109; Labour 1991, p. 131; and Hu 1998, p. 106.

Official unemployment rate from Labour 1995, p. 8; Yearbook 1999, p. 133; Yearbook 2000, p. 33; and Yearbook 2001, p. 33.

Alternate data for 1993-1999 are estimates of actual urban unemployment. In each case, the lower (higher) figure is calculated on the assumption that 60 per cent (or 40 per cent) of laid-off workers succeed in obtaining new employment. See $\mathrm{Hu}, 1998, \mathrm{p} .106$. The alternate rate for 2000 is from Hu 2001, Appendix Table 2.

\footnotetext{
${ }^{15}$ China's 1995 industrial census revealed the presence of widespread idle capacity. Average and median utilization rates for production facilities in 111 product lines stood at only 66 and 55 per cent (Yearbook 1997, pp. 454-455). Frequent press reports note a continuing shift from "seller's market" to "buyer's market" and indicate that domestic product markets remain in a state of excess supply. Despite the absence of systematic data, it seems likely that utilization rates have declined since 1995. A 1997 document notes that "more than 9 million staff and workers were laid off due to bankruptcy, partial or total suspension of production" (Roberts 2001, p. 17).
} 
With confusion surrounding the treatment of furloughed workers, many of whom hesitate to reveal new employment ties for fear of losing entitlements associated with their former employment, and with governments at all levels acting to limit the growth of measured unemployment, ${ }^{16}$ it is not possible to construct accurate and reliable unemployment measures even for China's urban economy. ${ }^{17}$ The following summarizes recent developments:

- $\quad$ Recent years have witnessed a steep rise in open unemployment among registered urban residents. The number of working-age individuals who find themselves without regular employment on account of dismissal, enterprise closure, bankruptcy, furlough, or semi-forced retirement certainly approaches and may well exceed 10 per cent of the urban labour force (excluding rural in-migrants from both numerator and denominator). This is the conclusion of Hu Angang, a prominent researcher of labour issues, whose unofficial estimates of urban unemployment appear in Table 7.

- Comprehensive and consistent data, if available, would probably show a continuing increase in the rate of joblessness among registered urban residents.

- Urban unemployment is typically structural rather than transitory. Current unemployment arises from "the mismatch between the new industrial structure and the low labour skills of the workers available" (Towns 2002). Laid-off personnel have little prospect of finding new positions that require the skills or offer the pay and benefits provided by their former employment. Long-term joblessness is common among laid-off urban workers. The decline of uncompetitive industries has turned some localities, particularly in the northeast and north-western regions, into depressed areas with very high rates of unemployment and little hope of rapid recovery.

- Despite extensive layoffs, the urban formal sector still contains substantial pools of redundant workers. Commentators regularly point to state-owned industry, where employment has dropped from a 1993 peak of 44.9 million to only 21 million in 2000 , as sheltering large pockets of disguised unemployment (Yearbook 2001), p. 118.

- China's urban work force also includes considerable numbers of jobless migrants from rural villages. Since migrants are routinely excluded from urban safety nets, and since concerns about maintaining public order motivate urban authorities to exercise strict controls over rural migrants, it seems likely that the bulk of unemployment among migrants is transitory. Villagers who come to cities in search of employment either find work or leave.

${ }^{16}$ China's Supreme Court, for example, has forbidden lower courts to initiate bankruptcy proceedings involving large state enterprises without explicit permission. One possible motivation for this instruction, which appears to contravene China's bankruptcy statutes, is to limit the growth of officially measured unemployment (Ma 2001). Elsewhere, "some local governments refuse to let people register as unemployed for reasons as spurious as being able to eat meat regularly" (FrancePresse 2001).

17 Solinger's review of sources on urban unemployment leads her to conclude that "these numbers are truly unfathomable" (Solinger 2001, p. 688). 


\subsection{Domestic migration}

The People's Republic of China, established in 1949, inherited an economy with large regional differences in per capita incomes. Subsequent egalitarian reforms acted mainly to reduce inequality within the urban economy (socialization of private business) and within local village communities (land reform, collectivization) without reducing long-standing spatial income disparities. Chinese socialism was marked by a strong urban bias. To preserve urban amenities for the intended beneficiaries and to limit the cost of these special benefits, the state implemented an array of policies that created barriers between the urban and rural sectors. These measures produced a large expansion of the income gap between urban and rural residents. ${ }^{18}$ In the meantime, China's communes, which were expected to employ all able-bodied members, pushed labour utilization far beyond economically sensible limits. Rural reforms, initiated in the late 1970s, quickly revealed an immense reservoir of underutilized rural labour.

The combination of large urban-rural income differentials and the sudden release of huge amounts of labour from farming created strong incentives for migration of villagers to China's towns and cities. Long-standing underdevelopment of the urban service sector and rapid growth of the urban economy intensified these pressures by expanding the urban demand for unskilled labour.

The result was a growing exodus from villages in many parts of rural China. Initially, fast-growing rural-based TVEs provided the prime destination for migrant workers. During the 1990s, the slowdown of TVE growth, the creation of networks linking would-be village migrants to urban employment, ${ }^{19}$ rapid improvement of interregional transport and communication, the erosion of urban control systems that had formerly obstructed migrants' access to grain and housing, ${ }^{20}$ and further expansion of urban-rural income differentials channelled growing numbers of migrants to urban destinations.

Although there are no reliable estimates of the numbers leaving the villages or working in urban areas, the scale of domestic labour movement is enormous, quite possibly the largest in human history. Furthermore, there is considerable evidence that the size of what Chinese writers call the "human tide of farmer-workers" continued to increase during the 1990s. Apparently referring to the early 1990s, Hein Mallee asserts that "a consensus seems to have emerged that the number of rural migrants is probably between 50 and 60 million" (Solinger 1999, p. 17). Recent figures are considerably larger. Goodkind and West report that "By 1997, the Ministry of Public Security estimates that the floating population had grown to 100 million" (Goodkind and West 2001, p. 6.)

The recent deceleration of economic growth and the concomitant increase in urban unemployment might have the effect of quenching urban demand for migrant workers, particularly since many urban areas have established regulations and fees intended to limit the influx of rural migrants. ${ }^{21}$ This appears not to have occurred. Goodkind and West believe that "a decline in migration seems unlikely" (Goodkind and West 2001, p. 5). Quantitative support for this view comes from a national survey that collected 20-year employment histories from 1199 households. The results show that "the rapid rise in [off-farm] employment [of village residents] has continued even during the late 1990s, a time when

\footnotetext{
${ }^{18}$ During $1955-57$, for example, per capita grain consumption in rural and urban areas was nearly identical. During the ensuing two decades, average grain consumption rose in the cities, but declined in the villages (Trade 1984).

19 See Solinger 1999, p. 180, on the commercialization of domestic labour export.

20 See for example, Solinger 1999, p. 65 (housing) and pp. 129, 263 (grain).

${ }^{21}$ See for example, Lu et al. 2001. However, critics insist that such regulations "have no effect in reality, but only contribute to arbitrary collection of fees on farmers who look for work in cities" (Chen 2001, p. 15).
} 
some feared that macroeconomic conditions might keep rural residents on the farm or drive them back to the farm" (deBrauw et al. 2001, p. 22). The same survey shows a sharp decline in the proportion of off-farm work located in residents' home counties, which fell from 42.2 per cent to 29.8 per cent between 1990 and 2000 (deBrauw et al. 2001, Table 2). This suggests that an increasing proportion of migrants found work in urban destinations.

\subsection{Growing penetration of market forces}

In addition to major changes in urban employment security and in rural-urban migration, the 1990s brought gradual changes in employment arrangements which cumulatively resulted in a major expansion of market forces in the determination of hiring, dismissal, and compensation of Chinese workers.

In 1990, dismissal of regular urban workers was almost unknown. By the end of the decade, large-scale layoffs were widely seen as both necessary and beneficial. Published reports benchmark the change. In 1994, bankrupt and loss-making enterprises "could decide to reduce their staffs" but only with "the approval from the whole staff or union" (Chang 1994). As late as 1998, published commentaries said that "middle and small-sized firms and labour-intensive enterprises must try to fully use the labour resources of the country. . . [and] should avoid promoting profit by simply letting go unnecessary employees" (Jobs 1998). But three years earlier, "Wu Banguo, member of the Secretariat of the Party Central Committee. . . . urged enterprises to cut their surplus staff, which he stressed as 'important work for enhancing management"' (Sun 1995). Official emphasis on the employers' responsibility for securing new positions before dismissing redundant workers has declined steadily. In 2001, Premier Zhu Rongji, displaying his customary bluntness, "encouraged laid-off workers . . . to find jobs on the private labour market" (Zhu 2001).

Premier Zhu's comment epitomizes major changes in the role of the private sector during the 1990s. During the first reform decade, private business remained small, neglected, and scorned. Many entrepreneurs felt obliged to operate private firms under the "red hat" of collective ownership. Rapid expansion of private business in the face of severe restraints alerted growing segments of the policy community to the potential importance of the private sector to China's future prospects. Local governments began to follow the lead of provincial and local officials in Guangdong and Zhejiang by encouraging and supporting private business. National leaders, acting with great deliberation, reinforced this trend with a succession of reforms, including a constitutional amendment endorsing private business, a law governing "solely-invested enterprises," a decision to open the Communist Party to private entrepreneurs, and growing exhortations favouring support of "small and medium enterprises" - a term widely taken to refer to private enterprise.

In 1990, new employment typically resulted from job assignments in which local labour bureaux matched applicants to requests submitted by potential employers. Voluntary job transfers were unusual, often stalled by employers, and, when successful, widely remarked. This changed rapidly. A 1993 report noted that "managers are often helpless with the employees who break contracts. . . . many workers are ready to leave for more lucrative jobs" (System 1993). Employers now complain about "job hopping" by ambitious employees.

College graduates, formerly assigned jobs upon graduation, now routinely seek employment on their own. Thus "students from outside the city who swarm into Shanghai are challenging local graduates in the local job market" (Recruits 2000). 
Prior to the onset of reform, and even during the first reform decade, studies of wage determination found unusually low returns on educational attainment, with college graduates, for example, sometimes earning lower incomes than their less-educated colleagues. This changed rapidly during the $1990 \mathrm{~s}^{22}$ Ambitious and talented individuals sought risky but rewarding new careers in Shenzhen and other special economic zones and open cities. Foreign-invested firms played a leading role in bidding up the price for highly educated workers. Government agencies leaped into the fray, urged on by Song Defu, the Minister of Personnel, who insisted that "it is imperative to develop job fairs and labour markets" to achieve "a wide distribution of talent." After Zhuhai's special zone emphasized the new role of talent by "heaping large rewards on. .. outstanding scientists and technicians" and "sent a delegation to travel across the country in search of gifted people with high levels of education" in 1992, northern cities mounted a "counterattack" that "scoured the southern provinces for similarly trained and talented people" (Mu 1993). State enterprises, formerly bastions of egalitarianism, have taken up the challenge: in 2001, representatives of Shanghaibased Baosteel visited university campuses in the United States and other foreign countries to recruit "high-level professionals" for positions paying over US $\$ 70,000 .^{23}$ The same trend appears in studies of rural migrants. Comparing 1990 and 2000, deBrauw et al. find that "the evolution of China's labor markets" for village migrants "increasingly has rewarded formal education." The same applies in local markets: in Zhejiang, for example, "rural residents ... participating in local labor markets ... are being rewarded for their formal education" (deBrauw et al. 2001, pp. 20-21). ${ }^{24}$

These developments have vastly increased the impact of market forces on employment outcomes. Even so, movement in the direction of a market-based system is far from complete. Government agencies and party offices continue to appoint the executives, and sometimes even mid-level managers of large enterprises in industry and finance, particularly (but not exclusively) in the state sector. Business executives may have little or no say in the appointment of their own deputies. Government agencies continue to establish (and perhaps enforce) wage guidelines for state, collective and even for foreign-invested enterprises. ${ }^{25}$ The slow pace of change is evident in a December 2000 report that the Ministry of Labour and Social Security "has suggested a salary system that is based on actual work performed by different workers" in state enterprises (Liu 2000). There is continuing resistance to special compensation for managers: efforts to reward corporate leaders with stock options have encountered stiff opposition. One former state enterprise director reports that his only means of rewarding a particularly valuable subordinate was with gifts of company-owned apartments (1999 interview).

\footnotetext{
${ }^{22}$ Lee (1999), for example, finds that "the average wage for college graduates [working in state-owned industrial units] has increased dramatically since the late 1980s" (p. 713).

${ }^{23}$ Xiao 2001a, where salaries of US $\$ 48,300$ plus housing subsidies equivalent to US $\$ 24,150$ are mentioned.

24 "Formal education, even at a low level, equips migrants, who customarily speak a local dialect, with the ability to speak Mandarin (putonghua) and contend with life outside their region of origin" (Roberts 2001, p. 27).

${ }^{25}$ Professor Zhang Weiying of Peking University displayed a chart showing the Beijing municipal government's wage guidelines at a May 2000 conference attended by the author.
} 


\section{Wages and employment conditions}

\subsection{Wage Patterns}

Wage behaviour reflects the pattern of considerable, but incomplete transition to a system governed primarily by market forces visible in the institutions surrounding the determination of employment. Table 8 summarizes trends in money and real wages for the formal (mainly urban) sector. With the exception of the small and declining urban collective sector, all sectors show a strong upward trend in both money and real wages. Surprisingly, real wage gains accelerate during the second half of the 1990s despite slow job growth, extensive layoffs, and a modest deflationary trend. Wage behaviour in the state sector is particularly noteworthy for the unusual combination of large pay increases and massive layoffs visible during the second half of the 1990s.

The new prominence of market forces is readily apparent from Table 9, which summarizes wage changes in 14 large cities for the year ending in October 1998. The data reveal a wide dispersion of wage movements. The tendency to reward educational accomplishment is evident. There are large differentials in the movement of nominal wages across major economic sectors and, within manufacturing, among specific trades.

Data on labour costs in manufacturing for the same cities, summarized in Table 10, highlights the impact as well as the limitations of market-directed institutional change on China's urban economy. Comparing the figures for state enterprises with information about firms under "other" ownership (which includes shareholding, foreign-linked, and domestic private enterprises) demonstrates the competitive pressures generated by firms operating under recently established organizational forms. The "other" enterprise group consistently outperforms the state sector in the areas of value-added, sales revenue, and profit per unit of labour cost. And despite higher labour costs per worker, the share of labour in total costs is uniformly lower for the "other" category than in the state sector. Adjustments to reflect the probable understatement of labour costs in the state sector would further expand the already considerable productivity and profitability advantage enjoyed by the "other" firms. ${ }^{26}$

These data also suggest that, despite extensive market-leaning reforms, manufacturing firms operating under traditional ownership categories continue to face institutional barriers to raising efficiency, productivity, and profitability. The inability of state enterprises, despite their uniformly superior complement of equipment, investment funds, and technical capabilities, to consistently outperform the weak and declining urban collective sector demonstrates the remaining grip of tenure and tradition on the operations of state industry.

${ }^{26}$ Understatement of labour costs for state firms is most likely in two areas: pension costs, which typically include payments to current retirees but ignore the (much larger) accumulation of future liabilities, and housing. 


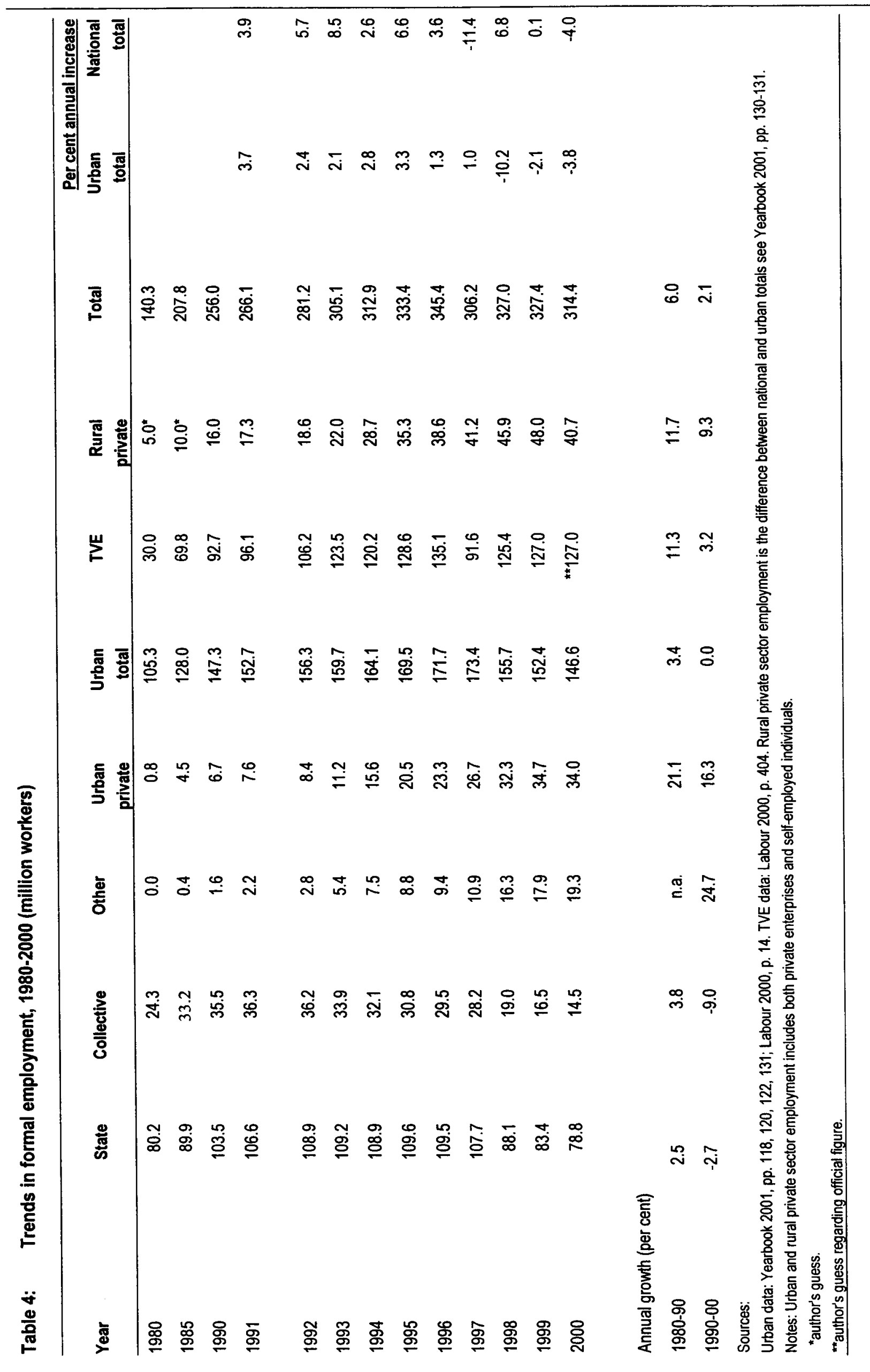


Table 9: Changes in nominal wages for staff and workers (zhigong),

October 1997 to October 1998

\begin{tabular}{|c|c|c|c|}
\hline & $\begin{array}{c}\text { Percentage } \\
\text { change }\end{array}$ & & $\begin{array}{c}\text { Percentage } \\
\text { change }\end{array}$ \\
\hline Fourteen cities & & Major economic sectors & \\
\hline Beijing & 4.0 & Farming, fishing, forestry & -19.6 \\
\hline Tianjin & 3.3 & Extractive & 5.0 \\
\hline Shanghai & -1.7 & Manufacturing & 1.8 \\
\hline Fuzhou & 10.2 & Geology \& water conservancy & -22.1 \\
\hline Chongqing & 6.1 & Transport \& communication & 5.1 \\
\hline Shenzhen & 5.4 & Wholesale \& retail trade & 1.2 \\
\hline Xi'an & 8.7 & Finance & 5.1 \\
\hline Chengdu & 4.1 & Real Estate & 17.7 \\
\hline Harbin & 5.5 & Education & 9.1 \\
\hline Jinan & -1.1 & Science \& technology & 8.4 \\
\hline Wuxi & 5.9 & Govt., party \& social orgs. & 7.8 \\
\hline Huangshi & 4.7 & & \\
\hline Chinhuangdao & 0.5 & Manufacturing - selected branches & \\
\hline \multirow[t]{2}{*}{ Foshan } & 1.7 & Textiles & -3.7 \\
\hline & & Garments & -9.4 \\
\hline Education levels & & Lumber processing & 7.7 \\
\hline Post-secondary education & 6.3 & Chemicals & 6.3 \\
\hline High school and equivalent & 3.3 & Ferrous metallurgy & -1.4 \\
\hline \multirow[t]{5}{*}{ Middle school and below } & 1.9 & Metal products & -3.5 \\
\hline & & Machinery & 2.5 \\
\hline & & Transport equipment & 0.4 \\
\hline & & Electrical machinery & 3.7 \\
\hline & & Electric power & 5.7 \\
\hline Source: Chen Gang et al. 1999 & $42-46$ & & \\
\hline
\end{tabular}


The figures in Table 10 point to wage indiscipline, an issue raised by W.T. Woo and others during the course of debates over productivity change in Chinese industry and echoed by Chinese writers, ${ }^{27}$ as a possible obstacle to improved performance, especially in the state sector. The share of labour in total cost for state sector manufacturers during 1997 was 14.5 per cent - nearly double the share of wages in gross output value reported for the entire state industrial sector in $1992 .{ }^{28}$ Although the comparison is not exact - GVIO is not the same as sales and the 1997 figures include non-wage labour costs - these figures suggest a considerable run-up in labour's share of total costs during the 1990s. Information in Table 11, which provides sectoral figures for labour costs broken down by region rather than by ownership, shows that labour costs (but not wages) are particularly high in China's western provinces. It is evident from the figures for wage trends (Table 8) and cost structure (Tables 10 and 11) that a modest reduction in labour's share of total cost, easily attainable through a modicum of wage restraint, could have produced steep increases in the near-zero profits recorded by state industry during 1997.

The suggestion of excessive wage increases, especially in the state sector, need not imply an inability or unwillingness of enterprise managers to control labour costs. China's historic legacy of egalitarianism makes it difficult for managers to impose large pay differentials. In banking, for example, egalitarianism "is still often seen in the salary and housing distribution, making it difficult to offer effective incentive to the staff" (Mi, Li, and Huang 2001, p. 91). Under these conditions, managers may feel obliged to grant broad wage increases in the hope of retaining key employees. Since private and foreign-linked firms enjoy far greater flexibility in wage setting, such efforts may not succeed. ${ }^{29}$ In banking, for example, officers' pay at foreign firms is about six times the figure at state-owned commercial banks. It is therefore not surprising that 32 of 169 senior managers employed by foreign banks at the end of 1999 were former employees of the Bank of China. The same bank hired 29 new college graduates in 1997 but lost 16 during the next four years (ibid.).

${ }^{27}$ See Woo et al. 1993. More recently, Yan and Chen (2001, p. 39) note that "the phenomenon of 'many people assigned to do a single person's task"' still exists, and criticize inadequate pay differentials within state firms, which leave technical workers underpaid, while unskilled workers receive high wages for performing tasks that command lower wages outside the state sector.

${ }^{28}$ The ratio of wages to gross output value in state industry rose from 7.0 per cent in 1980 to 7.3 per cent in 1985 and 7.5 per cent in 1992 (Industry 1993, pp. 26, 35).

${ }^{29}$ Fleisher and Wang (2001) find evidence of productivity-enhancing wage effects in Chinese enterprises. They also find that technical and administrative workers are consistently underpaid relative to production workers. 
Table 10: Information on 1997 labour costs under different ownership groupings for selected manufacturing sectors in 14 large cities

\begin{tabular}{|c|c|c|c|c|c|}
\hline & \multirow{2}{*}{$\begin{array}{l}\text { Labour } \\
\text { cost per } \\
\text { worker }\end{array}$} & \multicolumn{3}{|c|}{ Per yuan of labour cost } & \multirow{2}{*}{$\begin{array}{c}\text { Labour share } \\
\text { in total } \\
\text { cost }\end{array}$} \\
\hline & & $\begin{array}{l}\text { Value } \\
\text { added }\end{array}$ & $\begin{array}{r}\text { Sales } \\
\text { revenue }\end{array}$ & Profit & \\
\hline Overall & 9645.3 & 2.3 & 9.0 & 0.2 & 12.5 \\
\hline State & 9264.0 & 2.0 & 7.7 & 0.1 & 14.5 \\
\hline Collective & 5890.8 & 2.1 & 8.4 & 0.0 & 12.5 \\
\hline Other & 14405.5 & 3.3 & 13.3 & 0.6 & 8.5 \\
\hline Food-processing & 7119.0 & 2.9 & 22.7 & 0.1 & 4.8 \\
\hline State & 6436.6 & 1.9 & 16.0 & -0.2 & 6.7 \\
\hline Collective & 5897.1 & 3.4 & 16.5 & 0.6 & 6.8 \\
\hline Other & 14111.7 & 6.6 & 51.8 & 1.0 & 2.2 \\
\hline Garments & 7379.9 & 2.1 & 8.4 & 0.2 & 11.9 \\
\hline State & 6998.8 & 2.1 & 7.3 & 0.2 & 10.9 \\
\hline Collective & 6024.9 & 1.5 & 5.2 & 0.1 & 18.2 \\
\hline Other & 9170.5 & 2.6 & 11.3 & 0.3 & 10.0 \\
\hline Pharmaceutica & 10100.0 & 2.5 & 8.5 & 0.5 & 12.6 \\
\hline State & 9171.9 & 2.3 & 7.8 & 0.3 & 13.3 \\
\hline Collective & 8839.0 & 1.9 & 9.9 & 0.2 & 10.7 \\
\hline Other & 13819.0 & 3.1 & 9.7 & 0.9 & 11.5 \\
\hline Plastics & 8612.1 & 2.1 & 9.5 & 0.1 & 11.4 \\
\hline State & 8772.9 & 1.6 & 6.9 & -0.1 & 15.0 \\
\hline Collective & 5702.1 & 2.7 & 8.8 & 0.0 & 11.0 \\
\hline Other & 11171.8 & 2.3 & 12.1 & 0.3 & 9.6 \\
\hline Specialized equipment & 10300.4 & 1.3 & 5.5 & 0.0 & 19.5 \\
\hline State & 10208.7 & 1.1 & 5.0 & 0.0 & 21.6 \\
\hline Collective & 6220.5 & 1.8 & 5.4 & 0.0 & 19.6 \\
\hline Other & 15933.1 & 1.7 & 8.3 & 0.2 & 12.3 \\
\hline Transport equipment & 11707.9 & 2.7 & 8.9 & 0.2 & 12.3 \\
\hline State & 11497.5 & 1.7 & 7.3 & 0.0 & 11.9 \\
\hline Collective & 5943.9 & 2.2 & 11.5 & 0.2 & 14.2 \\
\hline Other & 16951.0 & 7.2 & 15.5 & 0.9 & 9.4 \\
\hline Electronics \& telecom. equip. & 9507.5 & 3.0 & 15.3 & 0.6 & 9.0 \\
\hline State & 7433.0 & 2.3 & 12.8 & 0.1 & 13.8 \\
\hline Collective & 7692.6 & 1.1 & 3.9 & -0.2 & 23.7 \\
\hline Other & 17863.2 & 4.3 & 20.9 & 1.6 & 5.6 \\
\hline
\end{tabular}


Table 11: Information on 1997 labour costs for manufacturing by region for 14 large cities

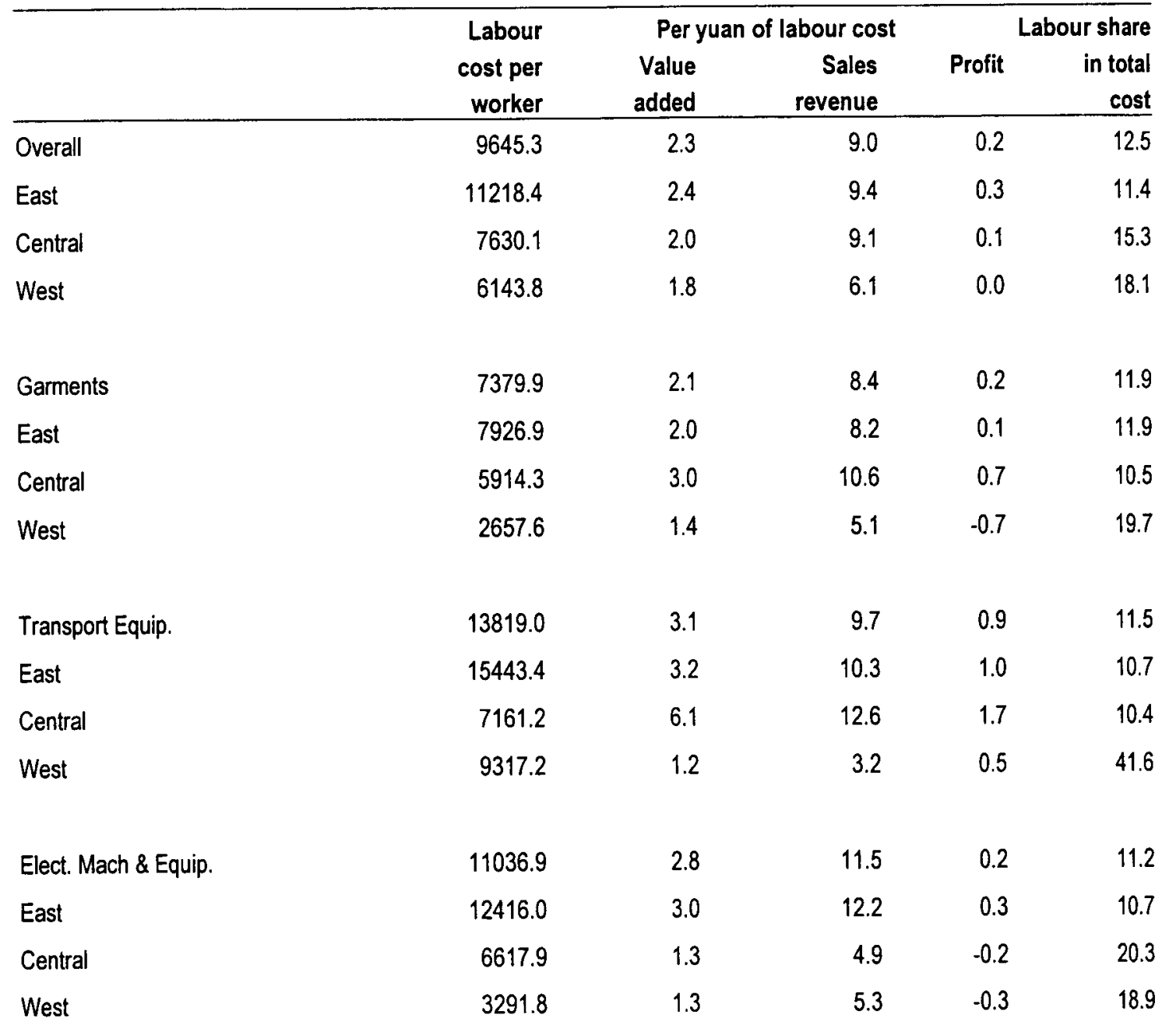

Source: Chen Gang et al. 1999, pp. 121-123.

Beginning in 1998, state sector pay increases have become an instrument of expansionary macro-policy. Official statements attribute declining growth momentum to insufficient aggregate demand..$^{30}$ China's government has designed a multiple response. In addition to expanded infrastructure investment financed with the proceeds from sale of treasury bonds, recent policy initiatives include large pay increases for state-sector employees and expansion of public holidays - both specifically intended to boost consumption spending. As a result, evidence of excessive wage and salary levels is not necessarily attributable to weak cost control efforts on the part of state sector managers.

Chinese sources rarely publish detailed comparisons of men's and women's wages. Studies based on small data samples show mixed results, with some finding a considerable gap between men's and women's wages and others indicating small and declining gender pay differentials. An econometric study based on indirect inference from data for 1988-1994 involving most of the urban labour force (but without information on specific individuals) found that China's urban employment system includes large gender pay differences that parallel conditions observed elsewhere in East Asia (Maurer-Fazio, Rawski, and Zhang 1999). Table 12 presents information from a Chinese source that provides unusually detailed

${ }^{30}$ The alternative advanced by a number of Chinese economists and endorsed by the present author, is to attribute the growth slowdown to structural causes (see Rawski 2000a; Rawski 2000b). 
information on gender pay differentials in fourteen large cities. These data confirm that, with some exceptions (notably textiles and education), average wages for women typically fall well below mean earnings for male workers. Occasional press comments point in the same direction: a "Report on the Social Status of Women" issued in September 2001 found that "the average yearly income ... of urban women was only 70.1 per cent of that of urban men" (Tang 2001).

\subsection{Employment Conditions}

The discussion here is limited to brief observations about hours of work, industrial safety, and working conditions. In each area, we see a combination of vigorous effort to establish suitable standards and limited success in enforcing official policy.

\section{Hours of work}

During the 1990s, new legislation reduced the standard working week from 48 to 44 hours (in 1994) and then to 40 hours (in 1995) (Jefferson et al. 2000, p. 809). These new provisions are widely implemented, especially in the public sector, in large cities, and in northern regions. There are, however, numerous reports of long hours. A 1991 issue of a Shanghai labour journal, for example, noted that union offices had received numerous letters from employees of foreign-linked firms "who complain that they have been subjected to relentless overtime" (Chan 2001, p. 43).

\section{Industrial safety}

Industrial safety is a long-standing problem in China, as in many industrializing nations. During the 1990s, the Chinese authorities have allowed increasingly open discussion of safety issues. Serious accidents are now widely reported in the press, along with promises of remedial action from top national leaders. Accident statistics, formerly shrouded in secrecy, are now routinely available, as when the New China News Agency reported in November 2001 that "Official figures show in the first half of this year, 64 major industrial accidents claimed 1,200 lives" (http://web12.cri.com.cn/english/2001/Nov/36619.htm). Safety concerns have figured prominently in the recent closure of large numbers of small-scale coal mines. China's State Council is in the process of drafting legislation on industrial safety for submission to the National People's Congress (ibid). 
Table 12: Men's and women's wages, 14 large cities, October 1998

\begin{tabular}{|c|c|c|c|}
\hline \multirow{2}{*}{ Sector } & \multicolumn{2}{|c|}{ Monthly wages for } & \multirow{2}{*}{$\begin{array}{r}\text { Index of women's wage } \\
(m e n=100)\end{array}$} \\
\hline & Men & Women & \\
\hline Overall & 953.9 & 805.2 & 84.4 \\
\hline Extractive & 562.5 & 422.4 & 75.1 \\
\hline Textiles & 616.2 & 633.2 & 102.8 \\
\hline Garments & 680.2 & 539.8 & 79.4 \\
\hline Paper & 1380.7 & 1134.4 & 82.2 \\
\hline Printing & 1213.5 & 820.0 & 67.6 \\
\hline Chemicals & 864.3 & 819.0 & 94.8 \\
\hline Ferrous metallurgy & 1036.9 & 567.0 & 54.7 \\
\hline Metal products & 897.8 & 739.2 & 82.3 \\
\hline Machinery & 804.3 & 677.2 & 84.2 \\
\hline Electrical machinery & 997.1 & 673.0 & 67.5 \\
\hline Electric power & 1579.4 & 832.6 & 52.7 \\
\hline Construction & 896.3 & 691.8 & 77.2 \\
\hline Post and telecommunications & 1429.0 & 1085.2 & 75.9 \\
\hline Retail sales & 761.4 & 685.3 & 90.0 \\
\hline Food \& drink & 1054.7 & 788.3 & 74.7 \\
\hline Finance & 1957.7 & 1332.4 & 68.1 \\
\hline Hotel & 1089.3 & 721.9 & 66.3 \\
\hline Health & 914.5 & 833.9 & 91.2 \\
\hline Education & 866.5 & 867.4 & 100.1 \\
\hline \multicolumn{4}{|c|}{ Summary data for sectoral wages } \\
\hline Standard deviation & 351.3 & 215.6 & 13.8 \\
\hline Coefficient of variation & 0.4 & 0.3 & 0.2 \\
\hline
\end{tabular}

\section{Working conditions}

China's socialist tradition includes strong emphasis on providing employees with suitable working conditions. In theory, trade unions, in their role as guardians of worker interests, are both qualified and empowered to campaign against unsatisfactory working conditions. However theory and reality need not coincide. Historically, trade unions have enjoyed limited independence and have often acted more as agents of the government than as representatives of the workers. More recently, the growing role of market forces has created conflicts between employers' efforts to limit costs and raise productivity and employees' concerns about workplace hazards, excessive discipline, and fair compensation. 
The result is the current transitional situation in which the rights and obligations of workers and employers, as well as the role of government regulation and trade union advocacy are neither clearly defined in law and regulation nor clearly understood in everyday practice. Rapid clarification of these issues seems unlikely, especially because ongoing institutional change will continue to inject elements of novelty and uncertainty into the employment nexus. ${ }^{31}$

Workers' complaints and protests arise in part from the consequences of economy-wide changes, including abolition of tenure and abrogation of official safety-net provisions that are largely unrelated to conditions in specific workplaces. But there are numerous instances of employer abuse, particularly in the south and in rural areas. Detailed accounts from Chinese sources, many reproduced in (Chan 2001), show that many Chinese workers face hazardous conditions, harsh discipline, and financial malpractice on the part of hard-driving employers. In extreme cases, these reports uncover circumstances tantamount to indentured servitude. ${ }^{32}$

Chinese authorities are well aware of such episodes. In supporting new provisions stipulating that "all workers and employees are authorized to join trade unions" and forbidding interference "with the act of joining a trade union," Liu Heng, Vice-Chairman of the All-China Federation of Trade Unions, speaks publicly of "rampant infringement of workers' legal rights." Liu's comments pinpoint the main source of difficulties: "We encourage the development of private and foreign enterprises . . . but . . . the owners . . . should be kind to employees and are forbidden to trespass workers' legal rights." Hu Min, a national legislator, is more specific: "working conditions and social security are not so ideal in some private, jointowned [(i.e. with foreign investment] and township enterprises. . . Overtime work. . . [may deliver] no extra pay, and . . . some employers go too far by conducting body searches of workers [suspected of stealing materials]. . . . workers are really the ones we should place priority on" (Union 2001).

In reality, there is no agreement on where China "should place priority." Local and provincial officials are expected to deliver high growth of output and exports and to limit expansion of unemployment. With labour in excess supply, official sentiment can easily tilt towards employers. A high inflow of foreign investment is widely viewed as an essential component of China's economic strategy. Since foreign investment clusters in industries in which low labour costs are central determinants of competitive advantage, local officials may feel obliged to tolerate harsh treatment of workers, particularly in view of the cost disadvantage arising from the appreciation of China's renminbi relative to most other Asian currencies since the 1997 financial crisis. Also relevant is the desire of local officials, especially in the south, to transfer the risk (and hence the responsibilities) associated with economic management to private entrepreneurs.

${ }^{31}$ The following sequence of reports illustrates the uncertainty surrounding labour issues. A Chinese report summarizes Vice-President $\mathrm{Hu}$ Jintao's address to a national trade union conference, in which Vice-President Hu said that unions should "focus on safeguarding the interests and rights of workers" and that workers' congresses "should be given more say in management and decision-making." The next day, the New York Times noted that workers in a state-owned silk factory found themselves "in a tense standoff with the authorities over their daring proposal to form a worker-run trade union in place of the official body that they say has failed to defend their interests." The group's leader "was detained by the police ... and involuntarily committed to a psychiatric hospital. . . one day after he spoke with Western reporters about the workers' grievances." (See Eckholm 2000; Seized 2000; Zhao 2000a).

${ }_{32}$ Gilley (2001, p. 51) reports that debt bondage and other exploitative employment relationships are "on the rise in China as migration flows grow and private business blossoms." 


\section{Productivity}

Aggregate output per worker provides the broadest measure of labour productivity. Since available data show near zero change in labour force participation rates during the 1990s, the path of output per head will exactly parallel the behaviour of output per worker. ${ }^{33}$ Table 13 shows an index of GDP per person derived from official figures. The data, which can be interpreted as an index of aggregate output per worker, accelerate from a 7.4 per cent annual growth rate during 1980/90 to a 9.5 per cent annual growth rate during 1990/97. ${ }^{34}$ Even though these figures may overstate productivity growth on account of (possibly increasing) overstatement of GDP growth and (also possibly increasing) understatement of population growth, there is little room to doubt the continued achievement of substantial growth of output per worker during the 1990 s.

Table 13: Growth of real GDP per person, 1980-2000 $(1990=100)$

\begin{tabular}{lc}
\hline Year & Index of real GDP per person \\
\hline 1980 & 47.6 \\
1990 & 100.0 \\
1991 & 107.7 \\
1992 & 121.5 \\
1993 & 136.4 \\
1994 & 151.9 \\
1995 & 166.0 \\
1996 & 180.0 \\
1997 & 194.0 \\
1998 & $* 207.1$ \\
1999 & ${ }^{2} 219.9$ \\
2000 & $* 235.4$ \\
2001 & $* 251.1$ \\
Average annual growth of real GDP per & \\
person & \\
$1980-90$ & 7.4 \\
$1990-97$ & 9.5 \\
* Official estimates of GDP growth for these years are believed to contain large overstatements. \\
Source: Yearbook 2001, p. 52. I obtain the figure for 2001 by using the officially estimated 7.3 per \\
cent real GDP growth for 2000/01 (Xu Binglan 2002, p. 1) and applying the rate of population growth \\
reported for 1999/2000 (see Table 2).
\end{tabular}

${ }^{33}$ The labour force participation rate derived from Table 2 (using Series B to measure labour force) falls within the range $56 \pm 0.3$ per cent throughout $1990-2000$.

${ }^{34}$ Calculation of growth rates after 1997 is omitted because the official reports appear to substantially exaggerate actual GDP outcomes. 
Estimates of real output per worker in various industrial ownership segments, reproduced in Table 14, confirm this picture of rising labour productivity during the $1990 \mathrm{~s}^{35}$ Analysis of total factor productivity, however, indicates a productivity slowdown during the 1990s, with declining productivity observed during 1993-1996 for industry as a whole, for state firms and, surprisingly, for shareholding and foreign-invested enterprises as well (Jefferson et al. 2000, pp. 797-799).

Table 14: Output per man-year in Chinese industry (Gross value, thousands of yuan at 1990 prices)

\begin{tabular}{|c|c|}
\hline Period & Gross output per man-year \\
\hline \multicolumn{2}{|c|}{ A. State enterprises } \\
\hline 1988 & 34.96 \\
\hline 1992 & 40.18 \\
\hline 1996 & 56.45 \\
\hline \multicolumn{2}{|c|}{ 8. Collective enterprises } \\
\hline 1988 & 18.34 \\
\hline 1992 & 24.86 \\
\hline 1996 & 52.76 \\
\hline \multicolumn{2}{|c|}{ C. Enterprises under other ownership } \\
\hline \multicolumn{2}{|c|}{ C1. Other domestic enterprises" } \\
\hline 1988 & 36.85 \\
\hline 1992 & 44.05 \\
\hline 1996 & 66.57 \\
\hline \multicolumn{2}{|c|}{ C2. Foreign-invested enterprises } \\
\hline 1988 & 83.97 \\
\hline 1992 & 86.55 \\
\hline 1996 & 124.53 \\
\hline \multicolumn{2}{|c|}{ C3. Shareholding enterprises } \\
\hline 1993 & 71.46 \\
\hline 1996 & 78.85 \\
\hline \multicolumn{2}{|c|}{ "category consists primarily of domestic private firms. } \\
\hline Source: Je & \\
\hline
\end{tabular}

${ }^{35}$ Comparison of industrial labour productivity figures becomes difficult after 1997 because of changes in the scope of employment (furloughed workers are omitted beginning with the data for 1998), changes in the calculation of industrial output (in 1995 and again in 1998), and because, starting with 1998, official reports appear to substantially exaggerate the growth of industrial production. 


\section{Distribution}

Prior to the start of economic reform in the late $1970 \mathrm{~s}$, official Chinese rhetoric emphasized equality and downplayed domestic income differentials. Modest income dispersion within urban organizations and model rural communities gave outsiders a distorted image of China as a highly egalitarian society. In reality, China's pre-reform economy harboured a wide income gap between privileged urbanites and the rural majority, as well as large spatial differentials, with higher incomes concentrated in the coastal east and low incomes clustered in the western, interior regions. One empirical review concluded that, at the beginning of reform, rough measures of Chinese distributive equity looked "not unlike those for India and Pakistan" and that "important features of China's income distribution" had "not improved significantly since the 1950s or even the 1930s" (Rawski 1982, pp. 25-26).

Initially, reform acted to reduce inequality. Steeply rising rural incomes diminished the urban-rural gap, while rapid growth along China's south-eastern coast allowed provinces formerly starved of investment funds to catch up with more favoured regions. By the late 1980 s, however, growth began to enlarge rather than diminish inequality.

Chinese and international observers agree that developments during the 1990 s have accelerated the growth of income inequality. Among many empirical studies, a collaboration between Chinese and international researchers on two large surveys conducted in 1988 and 1995 provides a representative account. The authors find that: "Between 1988 and 1995 income inequality increased sharply in China, making it one of the more unequal of Asian developing countries. Inequality rose in both rural and urban areas, but the great urban-rural gap is still the dominant contributor to overall inequality" (Khan and Riskin 1998, p. 252). These findings, which probably understate inequality because the surveys understate nonmonetary benefits provided to urban residents, ${ }^{36}$ underreport income from capital and fail to include the highest income earners, are echoed by numerous Chinese and international studies.

There is every reason to believe that the dispersion of incomes has continued to expand since 1995. The urban-rural gap continues to expand under the combined impact of large increases in formal sector wages and steep declines in the prices of agricultural commodities that may well have reduced rural incomes despite increased cash flow from migrant remittances and off-farm employment. ${ }^{37}$

\footnotetext{
${ }^{36}$ Income statistics typically include pension payments to current retirees, but invariably fail to account for the (much larger) value of pension rights available almost exclusively to urban residents. A further issue arises from the large transfers associated with urban housing reform. In Beijing, for example "public servants and employees working in government-funded institutions" can buy apartments of 20-30 square meters at subsidized prices. The market price of such apartments, transferred to lucky recipients for Y1,450 per square meter in 1997 and Y1,560 in 2001, reached Y4,772 in late 2001, indicating that the transfer associated with a typical apartment of 25 square meters amounted to $25 \times(4772-1560)$ or Y80,300 - a sum more than 35 times the average per capita income of rural residents in 2000 (Fu 2002; Xiao 2001b). In some cases, state-sector employees (for example, in civil aviation), are given apartments valued at US $\$ 200,000$ or more, free of charge (2001 interview).

37 "Purchase prices of farm and sideline products have already fallen for five consecutive years, with the cumulative drop amounting to 25.7 per cent, which has made the net income from agriculture drop for three consecutive years, while net incomes of rural villagers have dropped at an increasing rate for five consecutive years ( $\mathrm{Li} 2001$, p. 11). "Since 1997 . . the income of around 0.35 billion rural people did not increase with the GDP. Instead, it declined" (Lu et al. 2001).
} 
Within China's cities, differential income growth has favoured highly educated workers and persons employed in sectors (including finance, telecommunications, tobacco, electric power, aviation) where steep entry barriers enable high profits that are partly used to fund generous pay increases. ${ }^{38}$ Growing opportunities for talented workers to obtain high-wage employment in foreign-linked businesses, international organizations, and outside China have contributed to big pay hikes for employees with highly sought skills. At the same time, growing excess supply of unskilled and semi-skilled workers, including increased competition between unemployed urbanites and newcomers from rural areas, has acted to reduce even the nominal incomes of low-wage urban workers. ${ }^{39}$

Expansion of the east-west income gap has followed differential growth of output, and therefore of employment and personal incomes, favouring coastal areas and major urban centres. This process is in part fueled by foreign investment, which clusters in Guangdong, Fujian, Shanghai, Zhejiang, Jiangsu, Beijing, and Shandong. Despite large-scale injection of official development funds into interior regions under the government's plan to "Develop the West," market forces pull funds to the coast (Ye 2000). As one Chinese writer explained: "The time is not ripe for large-scale foreign investment in the west. Foreign investment takes profit as the objective. Return on investment is greater in the east than in the west. For this reason, it will be difficult to create a high tide of foreign investment in the west" (Li 2000, p. 19). Private funds follow the same logic.

Finally, differential access to non-farm income opportunities favouring educated individuals and persons located closer to urban centres or transport arteries contributes to the expansion of intra-rural inequality.

The result is high and rising inequality which shows signs of becoming embedded in China's social structure, as when one author observes that in Anhui province, high tuition costs at all levels, "the number of sons and daughters of farmers and laid-off urban workers who leave school is rising year by year, and the number of illiterates in the villages has begun to rise". ${ }^{40}$ Evidence of income concentration abounds, as when China Daily reports that 60 per cent of bank deposits are held by 8.7 per cent of the population (Chandler 2001). Recent studies indicate that inequality continues to grow:

\footnotetext{
"income gaps across China widened in the first six months of [2001] . . . according to figures from the National Bureau of Statistics. . . Accompanying the widening income gap between different regions was a widening gap between different social sectors. The Gini index . . . is 0.458 in China. This ranks China alongside the 40 countries with the greatest income gaps. (Jia 2001)."
}

\footnotetext{
${ }^{38}$ In Guangzhou, for example, "monopoly has resulted in large income gaps" with salaries in tobacco processing $(Y 4,461)$, postal and telecom services $(Y 3,265)$, and aviation $(Y 14,200)$ running far above the city-wide average of Y1,693 (Monopoly 2001).

${ }^{39}$ Large-scale survey data show a 21 per cent drop in the nominal incomes of primary school graduates within the lowest income quintile among urban residents between 1988 and 1995; average urban incomes rose by 66 per cent during the same period (Gustafsson and Li 2001, pp. 127, 131).

${ }^{40} \mathrm{Lin} 2001, \mathrm{p}$. 18. The author notes that annual tuition at village primary schools is Y400. Per capita net income of Anhui rural households in 2000 averaged Y1,935 (Yearbook 2001, p. 324).
} 


\section{Summary, prospects and policy directions}

This study has reviewed developments affecting China's labour markets during the past decade. Quantitative appraisal of recent trends is complicated by an apparent deterioration in the quality of Chinese economic statistics. This has occurred despite strenuous efforts by the National Bureau of Statistics to improve the quality of its measures and to align Chinese data with international norms. Difficulties arise from technical issues, notably the growing institutional complexity of China's economy and the reduced willingness of respondents to provide timely, complete, and reliable information; and also from the growing prevalence of data manipulation at all levels.

Nevertheless, the recent development path of China's labour economy is clear.

The population and labour force have continued to grow, but at declining rates.

Trends in the sectoral attachment of China's immense work force unfolded along familiar lines, with the number and proportion of workers in farming and other primary occupations declining and the size of the work forces in tertiary occupations increasing substantially.

Growth of formal employment has declined sharply. Average annual absorption of workers into formal employment dropped from roughly 11.6 million during 1980/90 and 15.5 million during 1990/95 to a negative 3.8 million during 1995/2000. As noted above, it seems likely that recent figures overstate employment in TVEs, in which case the decline in labour absorption would be larger than what is shown in Table 5 .

The locus of job creation has moved from SOE and TVE, prominent during the 1980 s, to employers in what Chinese sources describe as "other ownership arrangements," including domestic private firms, shareholding entities, and foreign-linked businesses.

Large-scale layoffs of redundant workers, the state enterprise sector, but also in urban collectives, rural TVE firms, and government agencies, have reinforced the effect of smaller numbers of new jobs. The exact numbers of furloughed workers are unclear, but the total appears to exceed 30 million workers (Table 6).

The combination of massive layoffs and slow job creation has resulted in the emergence of substantial open unemployment among China's urban populace. Official figures showing unemployment rates of approximately 3 per cent understate the extent of joblessness among registered urban residents. Chinese researchers provide more plausible estimates showing national urban unemployment approaching 10 per cent (Table 7). All these figures exclude redundant employees, transitory joblessness among migrants arriving from rural areas, and underemployment within China's rural work force.

Out-migration of villagers seeking work in China's towns and cities has become a major feature of China's labour scene. The number of migrants continues to increase, possibly to more than 100 million, despite a marked deceleration of economic growth.

The past decade has brought growing penetration of market forces into China's labour economy. In addition to increased domestic migration and large-scale layoffs of redundant workers, important new developments include the emergence of private business as a leading source of new jobs, the gradual replacement of official job assignments with competitive recruiting, and increased job mobility, especially among well-educated workers. 
Wage data display growing differentials among different trades, localities, and job categories, a new pattern that reflects the rising impact of market forces. Nonetheless, official interventions continue to affect urban wages. Inappropriately high wages contribute to poor financial performance, especially in the state sector. Beginning in 1998, official policy has mandated large increases in urban wages as part of expansionary macroeconomic policy designed to raise consumer spending. For China, as for other Asian nations, available data indicate that male workers are paid considerably more than female employees.

Working hours, industrial safety, and working conditions are areas in which we observe a substantial official effort to legislate standards combined with uneven enforcement.

Despite problems of measurement, it appears that output per worker continued to increase during the 1990s.

Chinese and international observers agree that income inequality increased rapidly during the 1990s. Available data, which appear to understate the degree of income inequality, suggest that China is rapidly emerging as an exemplar of disequalizing development.

The changes reviewed in this study, particularly the slowdown in job creation and the emergence of substantial open unemployment in the cities, have propelled employment issues to the top of China's national agenda.

As this is written in January 2002, short- and medium-term prospects for rapid expansion of employment opportunities appear poor. The National Bureau of Statistics maintains a partial compilation of urban employment figures: the series shows a decline of over 5 million jobs in 2000 , followed by a further drop of 4.9 million positions during the first three quarters of 2001 (Indicators 2001, p. 11). A senior analyst with the National Bureau of Statistics predicts "a gradual slowdown in the growth rate for domestic consumption," which may advance "at a much slower rate than previously expected" (Yan 2002). Ni Hongri, a researcher at the Development Research Centre under the State Council, observes that "China's economy has been slowing down month by month since the beginning of [2001] . . . as a result of falling demand both at home and abroad. . . . If the decline continues, the economy may face the danger of recession" (Xu 2001b). Large employers continue to announce impending job cuts: 30,000 at the Industrial and Commercial Bank of China, 55,000 at China Petrochemical Corp., "20,000 more workers" at the Ministry of Railways, and so on (Guo 2002; Leahy 2001; Xie 2001). With some analysts urging state enterprises to accelerate the dismissal of redundant workers (Wang 2001a; Yan and Chen 2001), it is not surprising to find China's Minister of Labour and Social Security stating that "there are not many new jobs available" (Zhao 2000b).

After enduring a period of declining formal-sector employment, the likelihood of attaining China's official objective of creating 8 million new jobs annually during the current 10th FiveYear Plan Period (2001-2005) appears slim. The immediate prospect is rather for further increases in joblessness. This is reflected in Labour Minister Zhang's announcement that China's plan for 2002 is "to redouble its efforts to keep its urban unemployment rate at around 4.5 per cent," a figure nearly 50 per cent above the official rates reported for 1997-2000 (Zhang 2001c). Concern about employment prospects is widely shared. Hu Angang, a prominent researcher in this area, identifies four key issues, among which "The first challenge is to endure employment pressure, which is not expected to be alleviated in the short term. . . . [and] has become a heavy burden on national economic development (Hu 2002).

Political leaders and economic policy-makers recognize the gravity of China's labour situation. In November 2001, front-page accounts reported the finding of a Central Economic Working Conference "that the country's employment situation is of political importance as it is vital to stability, reform, and opening up. Therefore committees of the Communist Party of China and governments at all levels should pay close attention to the employment situation and work to provide more jobs" (Demand 2001). 
Despite the government's realization that China faces a challenging employment situation, with further deterioration likely in the short term, it will not be easy to design and implement an effective policy response. It is increasingly evident that the initial diagnosis, which attributed slow job expansion and growing unemployment to a shortfall in aggregate demand arising primarily from the 1997 Asian crisis, was mistaken. If, as this survey maintains, China's labour market difficulties arise from a structural mismatch between the supply of and demand for workers, quick policy adjustments will not suffice to ameliorate high and rising unemployment. Instead, resolution of problems arising from slow employment growth will depend on progress towards structural change. China's reform experience, which now covers nearly a quarter century, demonstrates that structural change is slow, difficult and often painful.

For this reason, there is no menu of obvious measures with which Chinese officials can hope to reverse the recent decline of formal employment. The following discussion proposes policy directions that could help to accelerate the creation of new jobs. Initiatives in these directions, however, will not be easy, because they are likely to conflict with existing structures, policies, and objectives, including many that are deeply embedded in China's political economy.

\section{Promote private business}

Expanding China's private business sector, the largest source of new employment during the 1990s, is perhaps the most obvious employment-enhancing policy. Private business has grown rapidly, in part because of supportive policy changes, including favourable legislation, a supportive constitutional amendment, and, most recently, the important (and controversial) decision to admit private entrepreneurs into the ruling Communist Party. Despite these beneficial policies, further expansion of private business, and therefore of employment, remains massively restricted by artificial barriers. One Chinese commentator provides an apt summary by noting that private firms "need national treatment. . . . Though governments at all levels have attached great importance to the development [of private firms in their public statements, in practice such firms]. . still felt the inequality in government treatment when compared with the state-owned and foreign-invested enterprises" (Zhang 2001a, p. 82). During 2000 , for example, private businesses "accounted for about 30 per cent of the value of China's total industrial output" as well as substantial shares of activity in commerce, construction, and transport, but "received less than 1 per cent of total credit issued by banks" (Leggett 2002).

\section{Expand the private sector}

Expand the service sector which became "the main employment channel" during the 1990s. Further development in services can deliver substantial employment growth. Even though China has moved away from the "policy discrimination against the service sector" practised under socialist planning, the service sector's share of overall employment remains low in comparison with both developed and developing nations. One difficulty is that "monopoly has been commonplace inside service trades in China, with excessive restraints over market access and insufficient competition" (Li and Hou 2001). Requiring that the state sector "takes the lion's share in key fields such as the service sector, insurance, banking, telecom, education, and medical care, which all concern national security and [therefore] belong to the public" sector leads to high entry barriers, high prices, restrictions on output, and unnecessarily low growth of employment (Non-State 2002). 


\section{Promote rural development}

The rural sector, which has demonstrated its employment-creating potential in Japan, Taiwan, and elsewhere, provides numerous opportunities for policy initiatives oriented towards job creation. Chinese policy has long displayed a strong urban bias. ${ }^{41}$ Both the fiscal and financial systems transfer resources from village to city. The recent failure of rural consumption to deliver a fervently desired boost to aggregate demand may have alerted policymakers to the cost of neglecting investments in rural infrastructure, education and institutions that support the farm economy. Although no quick turnaround is possible under present circumstances, in which "the economy below county level is generally lacking growth momentum," an increase in resources applied to rural development could pay handsome employment dividends within a few years. (Xie and Yu 2001, p. 4).

\section{Avoid artificial increases in the cost of hiring workers}

Recent labour market developments include a surprising combination of excess labour supply with steep wage increases. Although some of the wage increases are needed to retain employees with special skills, many are not. Recent use of public sector wage increases as part of expansionary macro-policy seems ill-advised. ${ }^{42}$ The process continues: huge wage increases for civil servants - two pay raises and year-end bonuses for 45 million government employees "swelled the government payroll bill by nearly 40 per cent" in 2001 , with a further increase "in the pipeline for this year" (Chang 2002). As the effects of these measures spread across (and perhaps beyond) the public sector, the resulting increases in absolute and relative labour costs will discourage the expansion of labour-intensive industries and the use of labour-intensive technologies. China's ambition to create universal (at least for urban residents) programmes for unemployment insurance, retirement pensions and other social security provisions may be premature. Implementation of such programmes could adversely affect the demand for labour.

\section{Expand the role of market forces in determining the allocation of capital}

Investment decision-making is perhaps the weakest link in China's political economy, with many aspects displaying little change from circumstances under the pre-reform planning system. Consistently poor allocation of capital has generated a long history of low returns and a vast legacy of excess capacity. Recent efforts to boost economic growth by expanding public infrastructure spending and initiating a major programme to develop China's relatively poor western provinces have had unfortunate side effects, including conflicts with (already weak) efforts to reform investment behaviour, crowding out investment in the (mainly private) small business sector, and further reduction in investment returns (Macro 2001; Xu 2002b; Zhang 2001a). Excessive official involvement in investment decisions is a long-standing problem that continues to undercut the employment-generating capacity of China's economy.

\footnotetext{
${ }^{41}$ After the collapse of a poorly-built bridge resulted in 40 deaths, local officials in Chongqing municipality "gave each rural victim's family only half what they gave to an urban family" (Jiao 2001).

${ }^{42}$ A number of Chinese economists have recommended reductions in taxes (Xu 2001b). Tax cuts (or reductions in the growth of tax revenues, which are astonishingly high even after ample allowance for rampant overstatement) could match or surpass the expenditure stimulus from pay hikes while avoiding the negative consequences (higher labour costs, further pressure on China's heavy burden of formal and (mainly) informal public debt) associated with wage increases for government employees.
} 


\section{Reduce subsidies to capital-intensive undertakings}

Chinese policy heavily subsidizes capital-intensive activity, mainly by steering investment resources towards capital-using state enterprises, ${ }^{43}$ which receive the overwhelming share of bank loans and enjoy near exclusive access to listing opportunities on domestic and overseas stock and bond markets. The need to nurture state firms is offered as an explicit rationale for low interest rates. In addition, state firms working in "key sectors" or developing new technology may receive partial or complete exemption from interest costs. Finally, debt avoidance is commonplace. The rate of interest repayment (shouxilü) on loans held by China's four big state-owned commercial banks dropped from 84 per cent in 1994 to less than 60 per cent in 1998 and under 50 per cent in 1999 (Qiu, Li, and Cai 2000, p. 20). Easy avoidance of repayment persists: at the end of 2001 , "Chinese commercial banks are considering taking action against companies that deliberately dodge debts" (Xu 2001a).

Although deflation has eliminated the prior practice of lending at negative real rates, the current situation, in which (especially large-scale) state firms enjoy preferred access to loans at low nominal cost and (because of lenient treatment of defaulters) at even lower actual cost encourages China's largest users of capital to emphasize investments with limited employment creation potential. ${ }^{44}$ As a result, "the same volume of capital hires less labour in China than in other developing countries" ( $\mathrm{Zi} 2001$ ). Reports chiding large Chinese firms for failing to follow the example of "developed countries [where] large companies will put between 8 and 10 per cent of . . . overall assets into IT" - as opposed to the "minuscule" information technology investments revealed in an "official survey released. . . [by] the State Economic and Trade Commission", push investment decisions in directions that seem likely to limit employment creation.

\section{Avoid gigantism; avoid imitating the attempts of Japanese and Korean official agencies to "pick winners"}

China has announced plans to create "up to 50 giant State-owned enterprises" in the wake of China's entry into the World Trade Organization. These firms, situated in sectors like coal, steel, aluminum, shipbuilding, and engineering, are slated to receive "preferential policies," including "governmental financial support" and preferred access to equity markets. This move is intended "to increase competitiveness of Chinese industry in the globalized market" (Fu 2001; Groups 2001). This initiative which has drawn sharp commentary from critics who insist that successful enterprises "are not born by nature, self-styled or designated by the government," illustrates the conflict between employment promotion and other official objectives (Liu 2001, p. 51).

\section{Promote resource mobility}

China's current unemployment problem is exacerbated by institutional impediments to the matching up of workers with complementary resources needed to provide productive employment. Obstacles to the activation of idle state-sector facilities and equipment via merger, acquisition or bankruptcy, while much reduced from the $1980 \mathrm{~s}$, remain formidable. Such restrictions have the effect of reducing the effective stock of capital and hence the growth of both output and employment. Barriers to interprovincial trade, restrictions associated with China's system of residence permits (hukou), and other policies that limit the free flow of

\footnotetext{
${ }^{43}$ Lee (1999, p. 720) describes state-owned industry as operating under conditions of "extreme capital intensity."

44 "Financial institutions are willing to grant loans to large-sized enterprises or enterprise groups that enjoy good reputation. But these enterprises put the money into stock market because they cannot find good investment projects immediately" (Xie and Yu 2001, p. 6).
} 
commodities and resources generally act to limit the growth of productive employment, as do restrictions that prevent companies from selecting and compensating managers and workers on the basis of market criteria. ${ }^{45}$

\section{Reduce unproductive regulation; avoid re-regulation of economic activity}

Despite the beneficial impact of two decades of reform, China's economy remains burdened by a vast array of unproductive regulation. Reform is complicated by the regulators' desire to preserve their own power and authority and by the need to identify and preserve (or expand) the beneficial regulation that effective markets require. Unproductive regulation, including the costly and corrupt system of examination and approval (pizhun) and China's vast web of semi-legal fee collection, imposes immense costs on Chinese businesses, and extracts a huge price in terms of foregone employment opportunities. Given the inevitable difficulty of piece-by-piece deregulation, major downsizing of public agencies following the example of the central government's recent 50 per cent staff reduction appears to promise substantial benefits, ${ }^{46}$ not least a possible reduction in corruption and malfeasance. ${ }^{47}$

Re-regulation is particularly visible in the expanded scope of economic intervention by economic work commissions associated with the Chinese Communist Party, by the State Development Planning Commission, and by the Ministry of Finance. These developments threaten to stall or reverse many beneficial reform accomplishments. The possible negative impact of re-regulation on investment decisions is particularly worrisome. Re-regulation threatens to diminish China's growth prospects, and therefore to reduce opportunities to expand productive employment. ${ }^{48}$

Economists and policy-makers understand that China faces a difficult employment situation. Current labour market problems arise from long-standing and deeply rooted structural imbalances that are not amenable to rapid or easy correction. Short-term expansion of the already large gap between the supply of labour and the demand for workers appears likely. As a result, accelerating the growth of job opportunities now stands at the top of China's economic and political agenda. Achieving the goal of enlarged employment growth will not be easy. There are many feasible policy initiatives, but also many conflicts with competing objectives and with long-standing policy preferences and institutional arrangements. These circumstances ensure that employment concerns and labour market issues will remain close to the centre of China's economic and social policy agenda for the next decade.

\footnotetext{
${ }^{45}$ The suggestion that preferential treatment for large enterprise groups (but perhaps not for others?) should include "the right to distribute wages in line with. . . economic returns" illustrates the tentative approach to full wage liberalization (Groups 2001).

${ }^{46}$ Responding to "the call of the central government, [Beijing municipality] intend[ing] to slice the municipal government workforce in half" has laid off "tens of thousands of city employees. . . in a twoyear-long reorganization" (Wang 2002).

${ }^{47}$ An experienced Chinese civil servant advises the author that the conduct of central and provincial officials is "relatively good," whereas at the local level, problems are far more prevalent.

48 This theme is pursued in Rawski $2001 \mathrm{~b}$.
} 



\section{References}

An, Jilie. 2001. "Prospects for the Sugar Industry After China Enters WTO", in Jiage lilun yu shijian [Price Theory and Practice], No. 9, pp. 38-39.

Appleton, Simon, John Knight, Lina Song, and Qingjie Xia. 2001. Towards a Competitive Labour Market? Urban Workers, Rural Migrants, Redundancies and Hardships in China. Xerox dated May 2001. Corresponding author given as Song, c/o Institute of Contemporary China Studies, University of Nottingham (UK).

Chan, Anita. 2001. China's Workers Under Assault (Armonk NY, Sharpe).

Chandler, Clay. 2001. In China, the Rich Keep Getting Richer, in Washington Post Foreign Service. Available from:

$\mathrm{http}: / \mathrm{www}$. washingtonpost.com/ac2/wpyn?pagename $=$ article $\&$ node $=\& \operatorname{contentId}=\mathrm{A} 21307-$ $20010 c t 31$.

Chang, Hong. 1994. "Labour Law Guarantees Benefits for Workers", in China Daily (Beijing), 3 Mar. 1994, p. 1.

Chang, Tianle. 2002. "Civil Servant Pay Rise in the Pipeline", in China Daily (Beijing), 7 Jan. 2002, p. 2.

Chen, Gang et al. 1999. Zhongguo dazhong chengshi laodongli shichang gongzi jiawei [Market Wages of Labour in China's Large and Medium Cities] (Beijing, Laodong he shehui baozhang chubanshe).

Chen, Xiwen. 2001. "Analysis of the Situation of Agriculture and Rural Economy in the First Half of 2001", in China Development Review (Beijing, Development Research Centre of the State Council), Vol. 3, No. 4, pp. 7-18.

deBrauw, Alan, Jikun Huang, Scott Rozelle, Linxiu Zhang, and Yigang Zhang. 2001. The Evolution of China's Rural Labor Markets During the Reforms (Davis CA, University of California), Xerox dated Oct. 2001 from Department of Agricultural and Resource Economics.

Demand. 2001. "Rising Demand to Help Boost Economy", in China Daily (Beijing), 30 Nov. 2001, p 1.

Eckholm, Erik. 2000. "Silk Workers in Standoff With Beijing Over Union", in New York Times, A6.

Fleisher, Belton M., and Xiaojun Wang. 2001. "Efficiency Wages and Work Incentives in Urban and Rural China", in Journal of Comparative Economics (San Diego, CA, Academic Press).

France-Presse, Agence. 2001. Investors Left in Dark by Flawed Economic Data. Available from wysiwyg://55/http://biz/scmp.com/ZZZZEQSYAVC.html.

Fu, Jing. 2001. "Colossal SOEs to Advance WTO Role", in China Daily (Beijing), 8-9 Dec. 2001, p. 1.

Fu, Jing. 2002. "More Cheap Houses Promised", in China Daily (Beijing), 8 Jan. 2002, p. 2.

Gilley, Bruce. 2001. "Toil and Trouble", in Far Eastern Economic Review (Hong Kong, Dow Jones), 16 Aug., pp. 50-53. 
Goodkind, Daniel, and Loraine A. West. 2001. China's Floating Population - Definitions, Estimates, and Implications for Urbanization (Washington DC, International Programs Center, Population Division, US Census Bureau).

Groups. 2001. "What They Are Saying: Enterprise Groups Needed", in China Daily (Beijing), 10 Dec. 2001, p. 4.

Guo, Aibing. 2002. "Railways to Axe 20,000 Workers", in China Daily (Beijing), 2 Jan. 2002, p. 1.

Guo, Kesha. 1999. "Aggregate Demand or Structural Problems? How Distorted Economic Structure Constrains China's Economic Growth", in Jingji yanjiu [Economic Research] (Beijing), No. 9, pp. 15-21.

Gustafsson, Bjorn, and Shi Li. 2001. "The Anatomy of Rising Earnings Inequality in Urban China", in Journal of Comparative Economics (San Diego, CA, Academic Press), Vol. 29, pp. 118-135.

$\mathrm{Hu}$, Angang. 1998. Jiuye yu fazhan: Zhongguo shiye wenti yu jiuye zhanlue [Employment and Development: China's Unemployment Problem and Employment Strategy] (Shenyang, Liaoning renmin chubanshe).

$\mathrm{Hu}$, Angang. 2001. Creative Destruction of Restructuring: China's Urban Unemployment and Social Security (1993-2000) (xerox presented at seminar, University of Pittsburgh), 19 Oct. 2001.

Hu, Angang. 2002. "What They Are Saying: Four Challenges Ahead", in China Daily (Beijing), 7 Jan. 2002, p. 4.

Indicators. 2001. China Monthly Economic Indicators 2001, No.12 (Beijing, National Bureau of Statistics).

Industry. 1993. Zhongguo gongye jingii tongji nianjian 1993 [Statistical Yearbook of China's Industrial Economy 1993] (Beijing, Zhongguo tongji chubanshe).

Jefferson, Gary H., and Thomas G. Rawski. 1992. "Underemployment, Employment and Employment Policy in China's Cities", in Modern China, Vol. 18, No. 1, pp. $42-71$.

Jefferson, Gary H., Thomas G. Rawski, Li Wang, and Yuxin Zheng. 2000. "Ownership, Productivity Change, and Financial Performance in Chinese Industry", in Journal of Comparative Economics (San Diego, CA, Academic Press), Vol. 28, No. 4, pp. 786-813.

Jia, Heping. 2001. "Nation's Income Gap Widens", in China Daily Business Weekly (Beijing), 28 Aug. - 3 Sep. 2001, p. 20.

Jiao, Xiaoyang. 2001. "Farmers 'Cheaper' Than Urban People?" in China Daily (Beijing), 7 Feb. 2001, p. 4.

Jobs. 1998. "Labour-intensive Firms Key to Providing Jobs", in China Daily (Beijing), 14 July 1998, p 4.

Khan, Azizur Rahman, and Carl Riskin. 1998. "Income and Inequality in China: Composition, Distribution and Growth of Household Income, 1988 to 1995", in China Quarterly (Cambridge, UK, Cambridge University Press), No. 154, pp. 221-253.

Korzec, Michael. 1992. Labour and the Failure of Reform in China (New York, St. Martin's). 
Kung, James Kai-sing. 2001. Off-Farm Labor Markets and the Emergence of Land Rental Markets in China (Hong Kong, Division of Social Science, The Hong Kong University of Science and Technology).

Labour. 1987. Zhongguo laodong gongzi tongji ziliao 1949-1985 [China Labour and Wage Statistical Materials 1949-1985] (Beijing, Zhongguo tongji chubanshe).

Labour. 1995. Zhongguo laodong tongji nianjian 1995 [China Labour Statistical Yearbook 1995] (Beijing, Zhongguo tongii chubanshe).

- 1996. Zhongguo laodong tongji nianjian 1996 [China Labour Statistical Yearbook 1996] (Beijing, Zhongguo tongii chubanshe).

- 1998. Zhongguo laodong tongji nianjian 1998 [China Labour Statistical Yearbook 1999] (Beijing, Zhongguo tongii chubanshe).

- 1999. Zhongguo laodong tongji nianjian 1999 [China Labour Statistical Yearbook 1999] (Beijing, Zhongguo tongji chubanshe).

- 2000. Zhongguo laodong tongji nianjian 2000 (Beijing, Zhongguo tongji chubanshe).

Leahy, Joe. 2001. "ICBC to Cut 30,000 Jobs in Restructuring", in Financial Times (London), 25 Sep. 2001, p. 22.

Lee, Young. 1999. "Wages and Employment in China's SOEs, 1980-1994: Corporatization, Market Development, and Insider Forces", in Journal of Comparative Economics (San Diego, CA, Academic Press), Vol. 27, No. 4, pp. 702-729.

Leggett, Karby. 2002. "Foreign Investment Not a Panacea in China", in Wall Street Journal, 14 Jan. 2002, A1.

Li, Chacha. 2001. "Current Conditions in China's Macroeconomy: Present Circumstances, Problems, and Response", in Guoyou zichan guanli [State Asset Management], No. 8, p. 11.

Li, Shantong, and Yongzhi Hou. 2001. "Third Strategic Objective of Modernization Drive Calls for Rapid Expansion of Service Trade", in China Development Review (Beijing, Development Research Centre of the State Council), Vol. 3, No. 4, pp. 37-50.

Li, Xiaoxi. 2000. "Economic Prospects for 2000", in Zhongguo gongye jingji

[China Industrial Economy], No. 2, pp. 16-21.

Lin, Jiang. 2001. "Chaotic School Fees: Causes and Response", in Jiage lilun yu shijian [Price Theory and Practice], No. 8, p. 18.

Liu, Li. 2000. "SOE Pay Revamp for Jobs Well Done", in China Daily (Beijing), 21 Dec. 2000 , p. 2.

Liu, Shijin. 2001. "Options for the Development Pattern of China's Automobile Industry", in China Development Review (Beijing, Development Research Centre of the State Council), Vol. 3, No. 4, pp. 51-56.

Lu, Mai, Shukai Zhao, Nansheng Bai, Yang Xie, Huabo Huang, and Yijun Han. 2001. Retrospect and Prospect of Issues Related to Rural Labour Migration in China (Beijing, Guowuyuan Fazhanyanjiuzhongxin [State Council, Development Research Centre]), unpublished paper.

Ma, Chunhui. 1999. "Policy Choices for Expanding Domestic Demand", in Gaigezhazhi chubanshe [Reform] (Chongqing, China), No. 6, pp. 79-85. 
Ma, Jun. 2001. Slower Reforms in Wake of Global Slowdown China in the World Press. Available from www.chinaonline.com.

Macro. 2001. "With Continued Improvement in China's Macroeconomy, Don't Curtail Expansionary Fiscal Policy", in Guoyou zichan guanli [State Asset Management], No. 9, pp. 4-7.

Maurer-Fazio, Margaret, Thomas G. Rawski, and Wei Zhang. 1999. "Inequality in The Rewards for Holding up Half The Sky: Gender Wage Gaps in China's Urban Labour Markets, 1988-1994", in China Journal (Canberra, Contemporary China Centre, Australian National University), No. 41 , pp. 55-88.

Measures. 1999. "Measures Suggested to Reduce Unemployment", in China Daily (Beijing), 29 Jan. 1999 , p. 4.

Meng, Lian. 1999. "Analysis of Economic Conditions and Policies During the Past Several Years", in Gaigezhazhi chubanshe [Reform] (Chongqing, China), No. 3, pp. 73-82.

Mi, Jianguo, Yang Li, and Jinlao Huang. 2001. "The Challenges from the Opening of Banking Service Market in China", in China Development Review, (Beijing, Development Research Centre of the State Council), Vol. 3, No. 4, 83-96.

Monopoly. 2001. "Breaking Monopoly is a Must", in China Daily (Beijing), 10-11 Nov. 2001, p. 4.

Mu, Zi. 1993. "Scramble for Talent Spreads Across Nation", in China Daily (Beijing), 26 Oct. 1993, p 4.

Nation. 2000. "Nation Moves Boldly Forward", in China Daily (Beijing), 6 Mar. 2000, p. 5.

Non-State. 2002. "Non-State Economy Plays Big Role", in China Daily (Beijing),

9 Jan. 2002, p. 4.

Poverty. 2001. China: Overcoming Rural Poverty (Washington DC, World Bank).

Qiu, Yuemin, Bing Li, and Youcai Cai. 2000. "Losses of State-owned Commercial Banks: Causes and Policy Suggestions", in Jingi gongzuozhe xuexi ziliao [Study Materials for Economic Workers] (Beijing, Guowuyuan Fazhanyanjiuzhongxin [State Council, Development Research Centre]), No. 44, pp. 18-26.

Rawski, Thomas G. 1982. "The Simple Arithmetic of Chinese Income Distribution", in Keizai kenkyu [Economic Research] (Tokyo), Vol. 33, No. 1, pp. 12-26.

Rawski, Thomas G. 1994. "Progress Without Privatization: The Reform of China's State Industries", in The Political Economy of Privatization and Public Enterprise in Post-Communist and Reforming Communist States, edited by V. Milor (Boulder CO, Lynne Rienner).

Rawski, Thomas G. 1999. China: Prospects for Full Employment (Geneva, International Labour Office).

Rawski, Thomas G. 2000a. "China's Move to Market: How Far? What Next?", in China's Future: Constructive Partner or Emerging Threat?, edited by T. G. a. D. Carpenter, James A. (Washington DC, Cato Institute).

Rawski, Thomas G. 2000b. "The Political Economy of China's Declining Growth", in Peter Lloyd and Xiaoguang Zhang (eds.), China in the World Economy (Aldershot, Edward Elgar), pp. 28-42. 
Rawski, Thomas G. 2001a. "China by the Numbers: How Reform Has Affected China's Economic Statistics", in China Perspectives (Hong Kong, French Centre for Research on Contemporary China), No. 33, pp. 25-34.

Rawski, Thomas G. 2001b. "China Reform Watch: Turning Point Looming", in China Perspectives (Hong Kong, French Centre for Research on Contemporary China), No. 38.

Rawski, Thomas G. 2001c. China's GDP Statistics - A Case of Caveat Lector? Available from www.pitt.edu/ tgrawski/papers 2001.

Rawski, Thomas G. 2001d. "What's Happening to China's GDP Statistics?", in China Economic Review (New York, Elsevier Science), 12.4, pp. 347-354

Rawski, Thomas G., and Robert W. Mead. 1998. "On the Trail of China's Phantom Farmers", in World Development (Amsterdam, Elsevier Science), Vol. 26, No. 5, pp. 767-81.

Rawski, Thomas G., and Wei Xiao. 2001. "Symposium on Chinese Economic Statistics Introduction" in China Economic Review (New York, Elsevier Science), in press.

Recruits. 2000. City Lacks High-Tech Recruits. Available from http://www.chinadaily.com.cn/star/history/00-02-22/c04-city.html.

Roberts, Kenneth D. 2001. "The Determinants of Job Choice by Rural Labour Migrants in Shanghai", in China Economic Review (New York, Elsevier Science), Vol. 12, No. 1, pp. 15-39.

Schob, Chris. 2001. "Cracks in the Foundation? China's Regional Economies" (University of Pittsburgh), unpublished paper.

Seized. 2000. "China Labour Figure Seized", in New York Times, 16 Dec. 2000, A16.

Smith, Craig S. 2001. "China Reports 7.8\% Growth in Economy", in New York Times 18 July 2001 , W1.

Solinger, Dorothy J. 1999. Contesting Citizenship in Urban China (Berkeley, University of California Press).

Solinger, Dorothy J. 2001. "Why We Cannot Count the 'Unemployed"', in China Quarterly (Cambridge, UK, Cambridge University Press), No. 167, pp. 671-688.

Solinger, Dorothy J. (forthcoming). "Economic Informalization by Fiat: China's New Growth Strategy as Solution or Crisis?", in L. Tomba (ed.), On the Roots of Growth and Crisis: Capitalism, State and Society in East Asia (Milan, Giangiacomo Feltrinelli Foundation).

Sun, Shangwu. 1995. "State Firms Urged to Focus Reforms", in China Daily (Beijing), 23 Feb. 1995, p. 2.

System. 1993. "New Employment System Not Yet Perfect", in China Daily (Beijing), 28 Oct. 1993, p. 4.

Tang, Min. 2001. "Long Way to Go to Gain Gender Equality", in China Daily (Beijing), 24 Sep. 2001 , p. 4.

Towns. 2002. "What They Are Saying: Towns Offer More Jobs", in China Daily (Beijing), 2 Jan. 2002, p. 4.

Trade. 1984. Zhongguo maoyi wujia tongii ziliao 1952-1983 [Statistical Materials on China's Trade and Prices, 1952-1983] (Beijing, Zhongguo tongji chubanshe). 
Union. 2001. "Trade Union Law Amended", in China Daily (Beijing), 5 Nov. 2001, p. 3.

Wang, Lihua. 2001a. "Problems and Responses in Implementing Debt-Equity Swaps", in Guoyou zichan guanli [State Asset Management], No. 9, pp. 22-25.

Wang, Xiaoya. 2001b. "Analysis of the Current Macroeconomic Situation", in Caimao jingji [Finance and Economics], No. 4, pp. 5-10.

Wang, Ying. 2002. "Beijing Government Slices Workforce to Raise Efficiency", in China Daily (Beijing), 3 Jan. 2002, p. 2.

Woo, Wing Thye, Gang Fan, Wen Hai, and Jin Yibiao. 1993. "The Efficiency and Macroeconomic Consequences of Chinese Enterprise Reform", in China Economic Review (New York, Elsevier Science), Vol. 4, No. 2, pp. 153-168.

Wu, Yunhe. 1997. "Census Nets Critical Info For Industry", in China Daily (Beijing), 3 Apr. 1997, p. 1.

Xiao, Mi. 2001a. "Baosteel Set to Steal Talent", in China Daily Business Weekly (Beijing), 20-26 Nov. 2001, p. 17.

Xiao, Zhu. 2001b. "The Money Pi", in China Daily (Beijing), 6 Dec. 2001, p. 10.

Xie, Fuzhan, and Bin Yu. 2001. "A Basic Judgment Over the Current Economic Situation", in China Development Review (Beijing, Development Research Centre of the State Council), Vol. 3, No. 4, pp 1-6.

Xie, Ye. 2001. "Sinopec Profits Slide", in China Daily (Beijing), 28 Dec. 2001, p. 5.

Xu, Binglan. 2002a. "Growth Kept Despite Weak Global Economy", in China Daily (Beijing), 1 Jan. 2002, p. 1.

Xu, Dashan. 2001a. "Debt Dodgers Targeted for Wipeout", in China Daily (Beijing), 15 Dec. 2001 , p. 5.

Xu, Dashan. 2001b. "Experts Advocate Tax Cuts", in China Daily (Beijing), 30 Nov. 2001, p. 5.

Xu, Dashan. 2002b. "Overall Tax Cut Unlikely", in China Daily (Beijing), 10 Jan. 2002, p. 5.

Yan, Tingbiao, and Hong Chen. 2001. "Major Issues and Ideas About State Enterprise Reform Under Present Conditions", in Guoyou zichan guanli [Management of State Assets], No. 9, pp. 37-39.

Yan, Xianpu. 2002. "Hike in Consumption Unlikely Scenario", in China Daily Business Weekly (Beijing), 8-14 Jan. 2002, p. 24.

Yang, Yixiong. 1998. "China's Unemployment Problem: Current Situation, Trends, and Choices", in In Zhongguo 21 shji jingji zouxiang (Beijing, Zhonggong zhongyang dangxiao chubanshe).

Ye, Yingnan. 2000. "Analysis of the Effectiveness of Current Monetary Policy", in Zhongguo jinrong [China Finance], No. 12, pp. 11-14.

Yearbook. 1997. Zhongguo tongji nianjian 1997 [China Statistical Yearbook 1997] (Beijing, Zhongguo tongi chubanshe). 
Yearbook. 2001. Zhongguo tongji nianjian 2001 [China Statistical Yearbook 2001] (Beijing, Zhongguo tongji chubanshe).

Zhang, Chenghui. 2001a. "Research Report on the Current Financing Situation of Privatelyowned Enterprises", in China Development Review (Beijing, Development Research Centre of the State Council), Vol. 3, No. 3, pp. 72-82.

Zhang, Liqun. 2001b. "New Features and the Recent development Trend of the Economic growth in China", in China Development Review (Beijing, Development Research Centre of the State Council), July 2001, pp. 24-37.

Zhang, Yong. 2001c. "Efforts Redoubled to Create $8 \mathrm{~m}$ Jobs", in China Daily (Beijing), 13 Dec. 2001, p. 1.

Zhao, Huanxin. 2000a. "Unions Vital to Workers' Rights", in China Daily (Beijing), 14 Dec. 2000 , p. 1.

Zhao, Shaoqin. 2000b. "State Eyes Job Pinch", in China Daily (Beijing), 8 Mar. 2000, p. 1.

Zhao, Yang. 2001. "Rural Tax and Administrative Fees Reform: A Major System Innovation Since the Policy of Contracting Outputs to Farm Households Was Adopted", in China Development Review (Beijing, Development Research Centre of the State Council), Vol. 3, No. 3, pp. 53-62.

Zhu, Qiwen. 2001. "Domestic Market Fuels Growth", in China Daily (Beijing), 6 Aug. 2001, p. 4.

$\mathrm{Zi}$, Xun. 2001. "Enterprise Overhaul Needed to Rise to WTO Challenge", in China Daily Business Weekly (Beijing), 27 Nov. - 3 Dec. 2001, p. 15. 
